\title{
ANONIM ŞİRKET GENEL KURULUNA KATILMAYA YETKİLI VE KATILMAK ZORUNDA OLANLAR İLE KATILMAMANIN HUKUKİ SONUÇLARI
}

Arş. Gör. Merve SARIKAYA*

\section{ÖZET}

Türk Ticaret Kanunu (“TTK”) m. 407 ile Anonim Şirketlerin Genel Kurul Toplantılarının Usul ve Esasları ile Bu Toplantılarda Bulunacak Gümrük ve Ticaret Bakanlığı Temsilcileri Hakkında Yönetmelik (“BakTemYön”) m. 32/4 birlikte değerlendirildiğinde genel kurul (“GK”) toplantısına katılacak olan süjelerin ikili bir ayrıma tabi tutulduğu görülmektedir. Murahhas üyeler ile en az bir yönetim kurulu (“YK”) üyesinin, denetçinin ve BakTemYön'de sayılan hallerde bakanlık temsilcisinin GK'ya katılımı zorunlu iken; diğer YK üyeleri ile pay sahiplerinin toplantıya katılması isteğe bağlıdır. Diğer bir ifade ile pay sahipleri ile diğer YK üyeleri açısından genel kurula katılım bir hak iken; murahhas üyeler ile en az bir YK üyesi, denetçi ve bakanlık temsilcisi açısından aynı zamanda bir zorunluluktur.

Çalışmamızda öncelikle GK'ya katılmaya yetkili ve zorunlu olanlar tek tek ele alınacak, daha sonra toplantıya katılmak zorunda olanların katılımı olmaksızın GK toplantısı yapılması halinde hangi hukuki müeyyidelerin söz konusu olabileceğine ve bu toplantıda alınan kararların akıbetine ilişkin doktrindeki görüşler ortaya konulacak ve varılan sonuçlar gerekçeleri ile siralanacaktır.

Anahtar Kelimeler: Genel Kurul, Katılım, Bakanlık Temsilcisi, Murahhas Üye, Murahhas Müdür, Denetçi.

DOI:10.33432/ybuhukuk.767359 - Geliş Tarihi: 11.07.2020 - Kabul Tarihi: 01.12.2020.

** Marmara Üniversitesi Hukuk Fakültesi Ticaret Hukuku Anabilim Dalı, merve.tugsavul@marmara.edu.tr, ORCID: 0000-0002-5796-2468. 


\title{
THE PERSONS AUTHORIZED AND OBLIGED TO PARTICIPATE IN \\ GENERAL ASSEMBLY OF JOINT STOCK COMPANY AND LEGAL CONSEQUENCES OF NON PARTICIPATION
}

\begin{abstract}
When evaluated together Art. 407/1 of the Turkish Commercial Code and Art. 32/4 of "Regulation on Procedures and Principles of the General Assembly Meetings of the Joint Stock Companies and the Representatives of the Ministry of Customs and Trade in these Meetings" (hereinafter "Regulation"), it can be seen that the ones who attend the general assembly meeting are subjected to a dual distinction. Despite the participation of executive directors as well as at least one of the board members, auditor and representative of the Ministry are mandatory; the attendance of other board members and shareholders is optional. In other words, while the attendance to the general assembly is a right for shareholders, the auditor and other board members; executive directors and at least one board member the ministry representative are obliged to attend the meeting.

In our study, firstly, those who are authorized and obliged to participate in the General Assembly will be handled one by one, then, in case of a general assembly meeting without participation of those under obligation, the opinions in the doctrine regarding which legal sanctions may come into question and the legal consequences of general assembly resolutions will be revealed and the conclusions reached will be listed.
\end{abstract}

Keywords: General Assembly, Attendance, The Representatives of the Ministry of Trade, Executive Director, Auditor. 


\section{Gíriş}

TTK m. 407/1 uyarınca pay sahipleri, bu konumlarından doğan haklarını kural olarak genel kurulda kullanırlar. Bu sebeple GK, şirketin işleyişine ilişkin bazı meselelerin görüşülüp karara bağlandığ bir platform niteliği taşır. Özellikle şirketin mali durumu, YK üyelerinin ve denetçilerin görevlerini layıkıyla yerine getirip getirmediği gibi hususlar GK'da görüşülür ve varılan sonuçlar pay sahiplerine haklarını kullanırken yol gösterir ${ }^{1}$. Örneğin YK üyelerinin üzerlerine düşen görev ve yükümlülükleri yerine getirip getirmedikleri finansal tabloların görüşülmesi ile tespit edilebilir (TTK m 424). Bu saptama, YK üyelerinin ibrası yahut azli konusunda yapılacak bir oylamada pay sahiplerinin hangi yönde oy verecekleri hususunda belirleyici olacaktır. Bu yönüyle GK'nın en önemli işlevlerinden biri bilgi ve karar alma mekanizması olmasıdır².

GK tarafindan verilen kararlar toplantıda hazır bulunmayan veya olumsuz oy veren pay sahiplerini de bağlar (TTK m. 423). GK kararları, çoğunluğun iradesi doğrultusunda şekillenir (TTK m 418/2, m. 421). Her ne kadar pay sahipleri GK’ya katılma yükümlülüğü altında bulunmasalar da, GK toplantısına katılma ve oy kullanma hakları, şirketin vereceği kararların şekillenmesinde kilit role sahip olacaktır³. Bu sebepledir ki GK toplantısına çağrının yapılış şekli (TTK m. 414), gündeme bağlılık (TTK m. 413), hangi kararların hangi nisaplarla alınacağı (TTK m. 418, m. 421) gibi hususlar kanun koyucu tarafından sıkı şekil şartlarına tabi tutulmuştur".

1 Tekinalp, Ünal (2013) Sermaye Ortaklıklarının Yeni Hukuku, 3. Baskı, İstanbul, Vedat, N. 13-08.

2 Pulaşlı, Hasan (2018) 6102 sayılı Türk Ticaret Kanunu'na Göre Şirketler Hukuku Şerhi, C. 1, 3. Baskı, Ankara, Adalet, s. 826.

3 Arslanlı Halil (1960) Anonim Şirketler II-III Anonim Şirketin Organizasyonu ve Tahviller, 3. Baskı, İstanbul, Fakülteler Matbaası, s. 106. TTK m. 1527 ile ortaklık haklarının GK'da kullanımının artırılması suretiyle özellikle çok pay sahipli şirketlerin GK’larında yaşanan güç boşluklarının önlenmesi amacıyla elektronik ortamda GK yapılması hukuki zemine kavuşturulmuştur, Yayla, Ümit (2013) Yeni Türk Ticaret Kanunu ve Sermaye Piyasası Kanunu Uyarınca Anonim Ortaklık Genel Kurulları Elektronik Genel Kurullar, İstanbul, On İki Levha, s, 41.

4 Arslanlı, s. 106. 
TTK m. 407'ye göre, murahhas üyeler ile en az bir YK üyesinin, denetçiler ve bakanlık temsilcisinin GK'ya katılması bir zorunluluktur ${ }^{5}$. Böylece 6762 sayılı Türk Ticaret Kanunu (“eTTK”) döneminde GK’ya katılmak zorunda olan, diğer bir ifade ile GK'ya katılımın bir yükümlülük haline geldiği kimselerin var olup olmadığı tartışması da açık bir yasal düzenlemeye kavuşmuş olmaktadır. Pay sahipleri ve diğer YK üyeleri ise genel kurula katılma hakkına sahip kişilerdir6

\section{GENEL KURULA KATILMAK ZORUNDA OLANLAR}

\section{A. MURAHHAS ÜYELER İLE EN AZ BİR YK ÜYESİ 1. eTTK Dönemindeki Durum}

“Toplantıya İştirak Hakkı” başlığı taşıyan eTTK m. 360, pay sahiplerinin şirket işlemlerine ilişkin haklarını kullanmaları için GK toplantısına katılma hakkını düzenlemekte, YK üyelerinin GK'ya katılımını bir zorunluluk olarak öngörmemekteydi ${ }^{7}$. Bu sebeple doktrinde bir görüş, YK üyelerinin de tıpkı pay sahipleri gibi GK toplantısına katılmayabilecekleri yönündeydi ${ }^{8}$.

5 7/8/1996 tarih ve 22720 sayılı RG'de yayımlanan “Sermaye Şirketlerinin Genel Kurul Toplantıları ve $\mathrm{Bu}$ Toplantılarda Bulunacak Sanayi ve Ticaret Bakanlı̆̆ı Komiserleri Hakkında Yönetmelik" m. 20/2'de YK üyelerinden en az birisinin olağan GK toplantılarında hazır bulunma yükümlülüğünden söz edildiğinden anılan yükümlülüğün olağanüstü GK’lar için de söz konusu olup olmadığı konusunda tereddüt bulunmakta idi. TTK döneminde ise ilgili yükümlülügün hem olağan hem olağanüstü GK toplantıları bakımından geçerli olduğu kabul edilmektedir, Poroy, Reha/Tekinalp, Ünal /Çamoğlu/Ersin (2019) Ortaklıklar Hukuku I, 14. Baskı, İstanbul, Vedat, N. 680.

6 Bir GK kararı yahut esas sözleşme ile pay sahiplerinin GK'ya katılımının bir yükümlülük olarak belirlenmesi mümkün değildir. Öte yandan bu yükümlülük pay sahiplerinin üçüncü kişilerle yapacağı oy sözleşmeleri ile kararlaştırılabilirse de bu halde de yükümlülük şirkete karşı değil, oy sözleşmesinin diğer tarafına karşıdır, Teoman, Ömer (2012) "Yürürlükteki Hukukumuza ve Türk Ticaret Kanunu Tasarısına Göre Anonim Ortaklık Genel Kurul Toplantılarına Katılmak Zorunda Olanlar”, Tüm Makalelerim C.3, İstanbul, On İki Levha, s. $222, \mathrm{dn} .1$.

7 eTTK m. 353/1.9 uyarınca denetçilerin GK toplantısına katılma yükümlülüğünün açıkça düzenlenmiş olması YK üyeleri için de benzer bir yorumun yapılıp yapılamayacağı noktasında tereddütlere sebep olmakta idi. Nitekim bu anlamda asıl bilgi verme 
Diğer görüşe göre, YK üyeleri ile şirket arasındaki hukuki ilişkinin vekâlet akdine dayanması nedeniyle YK üyelerinin GK toplantısına katılma zorunluluğu bulunduğundan hatta bu yükümlülüğün bizzat yerine getirilmesi gerektiğinden bu kişilerin GK toplantısında hazır bulunması gerektiği savunulmakta idi'.

Ayrıca YK üyelerinin şirkete karşı bağlılık (sadakat) borcu ve özen yükümlülüğü bulunduğundan ve bunlar 818 sayılı mülga Borçlar Kanunu (“eBK”) uyarınca sözleşmeye konu işin bizzat yapılması noktasında kendini gösterdiğinden (eBK m. 390/3; TBK m. 506/1) üyelerin, YK toplantılarına bizzat katılmakla mükellef oldukları, katılımın bir temsilci aracılığı ile gerçekleştirilemeyeceği (eTTK m. 330; TTK m. 390/2) ${ }^{10}$; bu kuralın GK'ya katılım için de uygulanması gerektiği ifade edilmekte idi ${ }^{11}$.

Son ve belki de en önemli husus, bilgi alma hakkının muhatabı doğrudan YK üyeleri olduğundan ve özellikle bu kişilerin ibraları, azli gibi konularda sağlıklı bir karar alınabilmesi için GK toplantısında hazır

yükümlüsünün şirketin temsil ve ilzama yetkili olan YK olması gerektiği doktrinde savunulmaktaydı, Kaya, Arslan (2001) Anonim Ortaklıkta Pay Sahibinin Bilgi Alma Hakkı, Ankara, Banka ve Ticaret Hukuku Araştırma Enstitüsü, s. 179 vd.

8 Doğanay, İsmail (1990) Türk Ticaret Kanunu Şerhi C. 1, 3. Baskı, Ankara, Feryal Matbaası, s. 929.

9 Teoman, Ömer (2012) “Anonim Ortaklıklarda Yönetim Kurulu Üyelerinin Genel Kurul Toplantılarına Bizzat Katılma Yükümü Var Mıdır?” Tüm Makalelerim C. 1-2 içinde, İstanbul, On İki Levha, s. 415 vd; Kaya, s. 184-185. YK üyeleri ile şirket arasında hizmet, adi ortaklık ilişkisi yahut nevi şahsına münhasır bir ilişki olabileceği görüşleri yanında, bu ilişkinin vekalet akdine dayandığı hakkında bkz. Akdağ Güney, Necla (2016) Anonim Şirket Yönetim Kurulu, 2. Baskı, İstanbul, Vedat, s. 279 vd.; Poroy/Tekinalp/Çamoğlu, C. 1, N. 544; Kırca, İsmail/Şehirali Çelik, Feyzan Hayal/Manavgat, Çağlar (2013) Anonim Şirketler Hukuku C. 1, Ankara, Banka ve Ticaret Hukuku Enstitüsü, s. 454.

10 Bu konu hakkında ayrıntılı bilgi ve YK üyesinin toplantılara katılmaması durumunda sorumluluğunun ortaya çıkma şartları için bkz. Çamoğlu, Ersin (2010) Anonim Ortaklık Yönetim Kurulu Üyelerinin Hukuki Sorumluluğu, 3. Baskı, İstanbul, Vedat, s. 77-80; Teoman, (2012a), s.418; Teoman, (2012b), s. 226.

11 Teoman, (2012a), s. 418; Bahtiyar, Mehmet/Hamamcioğlu, Esra (2014) Yeni TTK’ya Göre Anonim Ortaklık Genel Kurul Toplantıları, İstanbul, Beta, s. 72. 
bulunmaları gerektiğinden ${ }^{12}$ eTTK döneminde, kanunun lafzında açıkça yer bulmasa da YK üyelerinin GK'ya bizzat katılımı bir zorunluluk olarak kabul edilmekteydi ${ }^{13}$.

$\mathrm{Bu}$ tartışmanın sona erdirilmesi amacıyla TTK'da GK toplantısına katılımı zorunlu olan kişiler sayılmıştır. TTK m. 407/2'ye göre, murahhas üyeler ile en az bir YK üyesinin GK toplantısına katılması zorunludur. Aynı zorunluluk BakTemYön ${ }^{14} \mathrm{~m}$. 17'de de ifade edilmektedir. Aşağı̆da TTK döneminde murahhas üyeler ile en az bir YK üyesinin GK toplantısına katılması zorunluluğu irdelenecektir:

\section{Murahhasların Katılım Zorunluluğu}

Kanun'a göre murahhas üye, kendisine temsil yetkisi devredilmiş YK üyesidir (TTK m. 370/2) ${ }^{15}$. Temsil yetkisinin YK üyesi olmayan üçüncü bir kişiye devri halinde ise murahhas müdürden söz edilmektedir (TTK m.370/2).

12 Teoman, (2012a), s. 419. YK üyesinin katılımı olmaksızın alınan GK kararının iptali dahi gündeme gelebilir, Kaya, s. 185.

13 Teoman, (2012b), s. 225; Teoman, (2012a), s. 417.

14 RG, 28.11.2012 S. 28481 "Anonim Şirketlerin Genel Kurul Toplantılarının Usul ve Esasları ile Bu Toplantılarda Bulunacak Gümrük Ve Ticaret Bakanliğı Temsilcileri Hakkında Yönetmelik”.

15 Murahhas sıfatının yönetim ve/veya temsil yetkisini haiz kişilerden hangisine ait olacağına ilişkin tartışmanın temelinde eTTK m. 319 yatmaktadır. Hüküm uyarınca yönetim ve temsil birlikte devrildiğinden murahhas sıfatı hem yönetim hem temsil yetkisi bulunan kişiye ait olmaktadır. Yine de Ünal, hükmün yönetim ve temsilin birbirinden ayrı olarak devredilemeyeceği şeklinde yorumlanamayacağını ifade etmekteydi, Ünal, Mustafa (1982) "Anonim Ortaklıklarda Yönetim ve Yönetim Görevlerinin Murahhaslara Bırakılması", BATIDER, C. 10, S.3, s. 66. TTK'da yönetim ve temsilin ayrı ayrı devrine olanak sağlanmasına karşın tartışma sona ermiş değildir. Tekinalp'e göre, murahhas sıfatının doğabilmesi için yalnızca yönetim yetkisinin devri yeterli olmamaktadır, TTK m. 370/2 uyarınca murahhas üye ya da müdürden bahsedilebilmesi için yürütme ve imza yetkilerinin beraberliği gerekmektedir. Dolayısıyla TTK m. 370/2 hükmü ile TTK m. 367 hükmü birlikte ele alınmalı; bu sebeple temsil yetkisinin devri için de esas sözleşmede bu yönde bir hüküm bulunmalı ve bir iç yönerge çıkarılmalıdır, N. 12-68, 12-75. Bu yönde bkz. Arslanlı, s. 135. Kanun'da yalnızca temsil yetkisinin devri hükmünde murahhaslıktan bahsedildiğine dikkat çeken Kırca da, temsil yetkisi devredilmeksizin yalnızca yönetimin devri ile murahhas sıfatının kazanılamayacağını ifade etmektedir, Kırca, (Şehirali Çelik/Manavgat), s. 595. 
Hüküm, bazı hususların muğlaklığı sebebiyle doktrinde eleştirilmektedir. Teoman, TTK m. 407/2 hükmünün murahhas üyelerden söz edip murahhas müdürleri göz ard1 etmesini bir eksiklik olarak nitelendirmektedir. Yazara göre her ne kadar hükmün lafzı murahhas müdürleri dışlasa da katılım zorunluluğunun hem murahhas üye hem de murahhas müdürler için söz konusu olması gerekir. Nitekim hem murahhas üyeler hem de murahhas müdürler temsil görevlerinin ifası ile ilgili olarak GK'ya bilgi verme yükümü altındadırlar' ${ }^{16}$.

Kanaatimizce, bilgi verme yükümlülüğü bakımından murahhas üyeler ile murahhas müdürler arasında bir fark bulunmamaktadır. Diğer bir anlatımla her iki grup da kendilerine bırakılan konularda yürütülen iş ve işlemler hakkında GK'ya bilgi verme yükümlülüğü altındadır. Dolayısıyla TTK m. 407/2'de yalnızca murahhas üyelerden bahsedilmesi karşısında, kanun koyucunun bir bilinçli susma halinde olduğu ve murahhas müdürlerin toplantıya katılmak zorunda olmadığı şeklinde bir yoruma gidilmemesi gerekir ${ }^{17}$. Yine de TTK m. 407/2'de murahhas müdürlerin de açıç̧a zikredilmesi mevcut tartışmaların sona ermesi bakımından gereklidir ${ }^{18}$.

Önemle belirtmek gerekir ki murahhaslar kendilerine yetki devredilen konularda en geniş bilgi sahibi olan kimselerdir; bu bağlamda anılan konularda tüm yetki ve sorumluluğu devralmış olmaktadırlar ${ }^{19}$. Ayrıca murahhaslar, organ sıfatını kazanarak tıpkı YK üyeleri gibi bağlılık ve özen

Yönetimin devri halinde murahhas sıfatının ortaya çıktığı yönünde bkz. Pulaşlı, C. 2 s. 1360-1361; Çamoğlu (Poroy/Tekinalp), C. 1, N. 536.

16 Teoman, (2012b), s. 232.

17 Bilinçli susma halinde kanunda herhangi bir boşluk bulunmayıp kanun koyucu meseleyi olumsuz şekilde sonuca bağlamaktadır. Kavram hakkında detaylı bilgi için bkz. Antalya, Gökhan/Topuz, Murat (2019) Medeni Hukuk Giriş Temel Kavramlar Başlangıç Hükümleri, 3. Baskı, Ankara, Seçkin, s. 317, 326. Murahhas müdürlerin de toplantlya katılma zorunluluğu bulunduğu yönünde bkz. Bilgili, Fatih/Demirkapı, Ertan (2013) Şirketler Hukuku, 9. Baskı, Bursa, Dora, s. 299.

18 Bu yönde bkz. Orbay Ortaç, Nurdan/Al Kılıç, Şengül (2018) “Anonim Şirket Yönetim Kurulu Üyelerinin ve Murahhasların Genel Kurula Katılması”, TFM, C.4, S. 2, s. 217.

19 Pulaşli, C. 2, s. 1382. 
yükümlülüğü altına girerler ${ }^{20}$. Bu sebeple, murahhasların GK'ya katılması, kendilerine bırakılan hususlarla ilgili pay sahiplerine bilgi verme ve yöneltilen sorulara cevap verme noktasinda zaruridir.

\section{En Az Bir YK Üyesinin Katılım Zorunluluğu}

TTK m. 407/2'ye göre GK'ya en az bir YK üyesinin de katılması şarttır. Kanaatimizce kanun koyucunun böyle bir hüküm sevk etmesinin altında yatan sebeplerden ilki YK’nın üst gözetim yükümlülügüdür. Her ne kadar TTK m. 553/2 kanundan veya esas sözleşmeden doğan bir görevi veya yetkiyi, kanuna dayanarak, başkasına devreden organlar veya kişilerin, bu görev ve yetkileri devralan kişilerin seçiminde makul derecede özen göstermediklerinin ispat edilmesi hâli hariç, bu kişilerin fiil ve kararlarından sorumlu olmayacaklarını öngörse de hükmün dar yorumlanmaması lazım gelir ${ }^{21}$. Nitekim TTK m. 375/1.e uyarınca YK’nın devredilemez görev ve yetkilerinden biri de üst gözetim yükümlülügüüür. $\mathrm{Bu}$ yükümlülük, murahhas üyelerin seçimini müteakip, bu kişilerin gözetimi ile onlara talimat verilmesini de $\operatorname{kapsar}^{22}$. Bu bağlamda en azından bir YK üyesinin GK toplantısında hazır bulunması, kendisine yetki devredilen konularda murahhas üye/müdürlerin görevlerini layıkıyla ifa edip etmediklerinin değerlendirilmesi noktasında etkili yollardan biri olacaktır.

Kanun koyucunun YK üyelerinden en az birine GK toplantısında hazır bulunma mükellefiyeti yüklemesinin altında yatan bir diğer sebep, TTK 370/2. c. 2'dir. Buna göre, temsil yetkisinin YK üyelerine devrinin yanı sıra üçüncü kişilere devri de mümkündür. Temsil yetkisinin üçüncü kişilere devrinde, kanun koyucu en az bir YK üyesinin de temsil yetkisini haiz olmasını şart koşmuştur. Anılan düzenleme ile kanun koyucu, temsil yetkisinin YK üyelerinden alınarak tamamen üçüncü kişilerin eline verilmesini engellemek istemiştir ${ }^{23}$. Öyleyse, murahhas müdüre yetki devri halinde, GK toplantısına

20 Kırca (Şehirali Çelik/Manavgat), s. 629.

21 Kırca (Şehirali Çelik/Manavgat), s. 612-613.

22 Tekinalp, s. 382-383; Pulaşlı, C. 2, s. 1382; Kurca (Şehirali Çelik/Manavgat), s. 613; Bahtiyar, Mehmet (2019) Ortaklıklar Hukuku, 13. Baskı, İstanbul, Beta, s. 231.

23 Çamoğlu (Poroy/Tekinalp), C. 1, N. 540; Kırca (Şehirali Çelik/Manavgat), s. 628; Bahtiyar, s. 232. 
murahhas müdürün yanı sıra en az bir YK üyesinin de katılması gerekir. Böylelikle, hükmün lafzında yer almayan murahhas müdürlerin de murahhas üyeler gibi GK toplantısına katılımının zorunlu olup olmadığı noktasındaki tereddütler de giderilmiş olmaktadır.

$\mathrm{Bu}$ düzenlemenin altında yatan nedenlerden biri de yönetim ve temsil yetkisinin bölünerek devredilmesi olasılığıdır. Bu noktada birtakım yetkilerin murahhaslara devredilip, diğer yetkilerin YK’da bırakıldığ 1 hallerde, devredilmeyen konularda pay sahiplerine bilgi verme yükümlülüğünü YK’nın yerine getirmesi gerekecektir. Bu görevin ifası için en azından bir YK üyesinin GK'da hazır bulunması gerekir. Ayrıca TTK m.375'te düzenlenen hususların murahhaslara devri mümkün olmadığından bu konularda da YK üyesinin GK'da hazır bulunarak bilgi verme yükümünü ifa etmesi gerekecektir.

Kanun'da GK'ya katılacak bir YK üyesinin nasıl belirleneceği konusunda açıklık bulunmamaktadır. Hükmün mehazını teşkil eden Aktiengesetz (“AktG”) $\$ 118 / 3$ 'e göre, yönetici kurul üyelerinin tamamının GK toplantısına katılımı zorunlu tutulmuştur. Buna rağmen TTK, tüm YK üyeleri için değil, içlerinden en az biri için bu yükümlülüğü düzenleme yolunu tercih etmiş fakat GK’ya katılacak bir YK üyesinin nasıl belirleneceği konusuna bir açılık getirmemiştir.

Teoman'a göre bu zorunluluk, kurul olarak çalışma yükümlülüğünün bir uzantısı olarak tüm YK üyelerine ait olmalıdır²4. Dolayısıyla, diğer YK üyelerinin "en az bir" ibaresinden faydalanarak sorumluluktan kurtulamaması gerekir. İlgili üyenin bir YK kararıla da seçilemeyeceğini ifade eden yazar, hukuki sorunların önüne geçilmesi için murahhasların yanı sıra tüm YK üyelerinin de toplantıda hazır bulunması zorunluluğunun getirilmesi gerektiği düşüncesindedir ${ }^{25}$. Kanaatimizce de, kanun koyucu tarafından tüm YK üyelerinin GK toplantısına katılımının öngörülmesi hukuken daha isabetli olmakla birlikte, fiili durumda GK toplantısına katılacak olan YK üyesinin YK tarafından seçilmesinin önünde de herhangi bir engel yoktur ${ }^{26}$. Bu şekilde GK

\footnotetext{
Teoman, (2012b), s. 233.

Teoman, (2012b), s. 235.

26 Bu yönde bkz. Orbay Ortaç/Al Kılıç, s. 218.
} 
toplantısından önce YK tarafından hangi üyenin toplantıya katılacağ belirlenebileceği gibi, böyle bir belirleme olmaksızın üyelerden birinin toplantıya fiilen katılımı da mümkün olmalıdır.

YK kararı ile belirlenen üyenin GK'ya katılmaması halinde sorumluluğun yalnızca ilgili üyeye mi yoksa tüm YK'ya mı ait olacağı sorusu akla gelmektedir. Her ne kadar doktrinde, YK’nın alacağı bir karar ile belirlenen üyenin GK'ya katılmaması halinde sorumluluğun sadece katılımı öngörülen üyeye ait olması gerektiği görüşünü savunan yazalar bulunmakta ise $\mathrm{de}^{27}$ kanaatimizce her durumda YK'nın alacağı böyle bir kararın YK üyelerinin sorumluluğu üzerinde bir etkisi olmayacak; GK’ya katılacak YK üyesi ismen belirlense dahi bu üyenin toplantıya katılmaması sonucu tüm YK müteselsilen sorumlu olacaktır (TTK m. 553).

GK toplantısına bir murahhas üyenin katıldığ ihtimalde, anılan murahhas üye aynı zamanda YK üyesi de olduğundan TTK m. 407/2'de öngörülen her iki katılım şartının gerçekleşip gerçekleşmediği sorusu akla gelebilir. Ancak kanundaki ifade "murahhas üyelerle en az bir yönetim kurulu üyesinin” şeklinde olduğundan kullanılan “-le” bağlacı "ve” olarak algılanmalı; murahhas üyenin yanında bir başka YK üyesinin de katılımı zorunlu görülmelidir.

\section{B. DENETÇí}

TTK m. 407/2'ye göre, GK toplantılarında hazır bulunması gerekli olanlardan bir diğeri denetçidir ${ }^{28}$. TTK'da denetçi, anonim şirketin bir organı olmaktan çıkarılmış ve denetimin TTK m. 399'a göre GK tarafından seçilecek bağımsız denetleme kuruluşları ile yeminli mali müşavir yahut serbest

\footnotetext{
27 Orbay Ortaç/Al Kılıç, s. 218-219.

28 Hükmün ilk halinde denetçi ile kendisini ilgilendiren konularda işlem denetçisinin de GK'da hazır bulunacağı öngörülmüştü. İlk kez TTK Tasarısı'nda düzenlenen işlem denetçisi, şirketin kuruluşu, sermaye artırımı, azaltılması, yapısal değişiklikler, menkul kıymet ihracı gibi konularda şirket işlem ve kararlarını denetlemek ile görevli kılınmış idi. İşte bu konuların görüşülüp karara bağlandığı GK’larda işlem denetçisinin toplantıya katılma yükümü düzenlenmişti. Ancak 6335 sayılı Kanun'un 41. maddesi ile işlem denetçisi madde metninden çıkarılmıştır,
} 
muhasebeci mali müşavirler eliyle yapılacağı yeni bir denetim sistemi öngörülmüştür.

Anonim şirketlerde denetçilerin görevlerini düzenleyen eTTK m. 353/1.9, GK toplantısına katılma yükümlülügünü düzenlemekte idi. Doktrinde bu yükümlülügün denetçilerin birden fazla olması halinde tamamı için geçerli olduğu ifade edilmekte idi $^{29}$. Anonim şirkette zorunlu bir organ olan denetçiler, eTTK döneminde pay sahiplerinin bilgi alma taleplerinin öncelikli muhatabı kabul edilmekteydi ${ }^{30}$. Bu anlamda pay sahiplerinin bilgi alma hakkını kullandığı platform olan GK'ya, denetçilerin bizzat katılımı bir kanuni yükümlülük olarak karşımıza çıkmaktayd $1^{31}$. Bu durum mülga Sermaye Şirketlerinin Genel Kurul Toplantıları ve $\mathrm{Bu}$ Toplantılarda Bulunacak Sanayi ve Ticaret Bakanlığı Komiserleri Hakkında Yönetmelik ${ }^{32}$ (“KomY”) m. 20'de de açıkça ifade bulmaktaydı.

AŞ’lerde denetim TTK m. 397 vd.'nda düzenlenmektedir. Buna göre, kanun koyucu ikili bir ayrım benimsemiş; TTK m. 398 kapsamında denetime tabi tutulacak AŞ’lerin Cumhurbaşkanınca ${ }^{33}$ belirleneceği, TTK m. 398/4 kapsamı dışında kalan AŞ’ler ile 4572 sayılı Kanun kapsamındaki kooperatifler ve bunların bağımsız denetime tabi olmayan üst kuruluşlarının ise bu fikra hükümlerine göre denetleneceği hükme bağlanmıştır ${ }^{34}$.

29 Teoman, (2012b), s. 223; Kaya, s. 170.

30

Kaya, s. 168.

31 Kaya, s. 168-169.

32 RG, 7/8/1996 S. 22720.

33 TTK m. 397/4 ile daha önceden Bakanlar Kuruluna verilen yetki, 700 sayılı Anayasada Yapılan Değişikliklere Uyum Sağlanması Amacıyla Bazı Kanun ve Kanun Hükmünde Kararnamelerde Değişiklik Yapılması Hakkında Kanun Hükmünde Kararnamenin (RG, 02.07.2018 S. 30471) 192 inci maddesiyle Cumhurbaşkanına verilmiştir.

Cumhurbaşkanınca henüz bir belirleme yapılmamıştır. Ancak hâlihazırda yürürlükte olan 2018/11597 sayılı Bakanlar Kurulu kararının 3. maddesi ile aktif toplamı 35 milyon TL, yıllık net satış hasılatı 70 milyon TL ve çalışan sayısı 175 kişi olma kriterlerini üst üste iki hesap dönemi aşan AŞ’lerin bağımsız denetim kapsamında olacağı düzenlenmiştir. Ne var ki TTK m. 397/5 uyarınca, bu Kanun kapsamında denetimin ve denetim raporlarının içeriğine ve raporun GK'ya sunulmasına ilişkin hususların Cumhurbaşkanınca çıarılacak yönetmelikle düzenleneceği belirtilse de bu konuda henüz bir düzenleme yapılmış değildir. 
Bağımsız denetim, şirket ve diğer menfaat sahipleri bakımından zaruridir ${ }^{35}$. Şüphesiz, bu gereklilik en çok şirket içerisinde kendini gösterir zira finansal tabloların denetlenmesi özellikle şirketin yönetimini üstlenen kişilerin daha dikkatli davranmasını sağlar ve hukuka aykırılıklara karşı caydırıcı bir mekanizma öngörür ${ }^{36}$. Böylece, mevzuata uygun hazırlanan finansal raporlar ile menfaat sahipleri, şirketin ekonomik durumunun gidişatı hakkında sağlıklı bilgiye kavuşmuş olurlar.

Denetim, pay sahiplerinin de menfaatine yapilır ve bu denetim neticesinde elde edilen sonuçlar pay sahiplerinin bilgi ve incelemesine sunulur. Nitekim TTK m. 437/2'de pay sahibinin GK'da denetçilerden denetimin yapılma şekli ve sonuçları hakkında bilgi isteyebileceği düzenlenmektedir. Denetçinin raporu pay sahiplerinin bilgi edinme hakkının kaynaklarından biridir $^{37}$. Bu önem sebebiyledir ki TTK m. 407/2'de denetçilerin GK toplantısına katılımı bir zorunluluk olarak öngörülmüştür. Birden çok denetçi bulunması durumunda denetçilerin tamamının katılımı gereklidir zira YK üyelerinde olduğu gibi en az bir denetçinin yükümlülügünden bahsedilmemesi ilgili yükümlülüğün bütün denetçiler bakımından söz konusu olduğunun bir ispatıdır ${ }^{38}$.

\section{BAKANLIK TEMSIILCİSI}

Anonim şirket GK'larına katılımı zorunlu tutulan son grup Bakanlık temsilcisidir. TTK m. 407/3'e göre, TTK m. 333 hükmü gereğince belirlenen şirketlerin GK toplantılarında Ticaret Bakanlığının temsilcisi de yer alacak; diğer şirketlerde, hangi durumlarda Bakanlık temsilcisinin GK'da bulunacağ 1 ve buna ilişkin genel esaslar Ticaret Bakanlığınca çıkarılacak bir yönetmelikle düzenlenecektir.

BakTemYön m. 32/1 uyarınca,

35 Kocabıyık, Sami (2018) Bağımsız Denetçinin Üçüncü Kişilere Karşı Hukuki Sorumluluğu, Ankara, Seçkin, s. 43.

36 Bağımsız denetimin diğer işlevleri hakkında ayrıntılı bilgi için bkz. Kocabıyık, s. 43-50.

37 Bahtiyar, s. 247.

38 Teoman, (2012b), s. 236. 
- Kuruluş ve esas sözleşme değişikliği işlemleri Bakanlık iznine tabi olan şirketlerin bütün GK toplantılarında,

- Diğer şirketlerde ise gündeminde, sermayenin arttırılması veya azaltılması, kayıtlı sermaye sistemine geçilmesi ve kayıtlı sermaye sisteminden çıkılması, kayıtlı sermaye tavanının arttırılması veya faaliyet konusunun değiştirilmesine ilişkin esas sözleşme değişikliği ile

- Birleşme, bölünme veya tür değişikliği konuları bulunan GK toplantılarında,

- GK'ya elektronik ortamda katılım sistemini uygulayan şirketlerin genel kurul toplantılarında,

- Yurt dışında yapılacak bütün GK toplantılarında,

- Yurt dışında yapılacak imtiyazlı pay sahipleri özel kurul toplantılarında

ve bunların ertelenmesi halinde yapılacak ikinci toplantılarda Bakanlık temsilcisinin bulunması bir zorunluluktur. Bunun dişındaki toplantılarda ise kural olarak temsilci bulundurma zorunluluğu bulunmaz. Ancak GK'y1 toplantıya çağıranların talep etmeleri ve bu taleplerin görevlendirme makamınca uygun görülmesi halinde Bakanlık temsilcisi görevlendirilir (BakTemYön m. 32/2).

TTK m. 422'ye göre, GK toplantı tutanağı, Bakanlık temsilcisi tarafından imza edilmediği takdirde geçersizdir. BakTemYön de, anonim şirket GK'larına katılımı zorunlu olan kişiler arasında Bakanlık temsilcisini sayarak, bu kimselerin katılmadığ 1 yahut toplantıyı terk ettiği hallerde alınan kararların geçerli olmayacağını ifade etmiştir (BakTemYön m. 32/4). 


\section{GENEL KURULA KATILMAYA YETKİLI OLANLAR}

\section{A. PAY ÜZERİNDE HAK SAHİBİ OLANLAR}

\section{Pay Sahipleri}

Pay sahiplerinin GK toplantısına katılma hak ve yetkisi bulunsa da bu durum bir zorunluluk arz etmez. Diğer bir ifade ile pay sahiplerinin GK'ya katılımı TTK'da bir yükümlülük olarak öngörülmediğinden katılımı zorunlu olan kimseler hariç olmak üzere, pay sahiplerinin GK toplantısına katılmaları ve toplantının bitimine kadar GK'da bulunmaları şart değildir ${ }^{39}$.

GK, pay sahiplerinden müteşekkil bir organdır. Dolayısıyla, GK’ya katılma hakkı kural olarak pay sahiplerine aittir. Gerçekten de TTK'nın ilgili hükümleri, GK toplantısına katılabilmek için pay sahipliğinin ispatını şart koşar. GK’ya katılım vazgeçilmez hak ${ }^{40}$ mahiyetinde olup, oy hakkı başta olmak üzere çeşitli pay sahipliği haklarının kullanım yeri de GK'dır. Pay sahibinin GK'ya katılma, asgari oy, dava ve kanundan kaynaklanan vazgeçilmez nitelikteki haklarını sınırlandıran veya ortadan kaldıran kararlar batıldır (TTK m. 447).

GK'ya katılım aynı zamanda kişisel nitelikte bir haktır. Bu durum TTK m. 425’in başlığından da anlaşılmaktadır. Kişisel nitelikte olması hem hakkın

39 Teoman, (2012b), s. 221; Bahtiyar/Hamamcioğlu, s. 55.

40 Pay sahibinin iradesinin önem taşımadığı, yalnızca pay sahibinin değil aynı zamanda ortaklığın temel yapısını da koruyan haklar vazgeçilmez nitelikte haklardır, Tekinalp, s. 301; Tekinalp (Poroy/Çamoğlu), C. 1, N. 870e vd. Vazgeçilmez hak kavramını detaylı bir şekilde ele alan Kırca, bu kavramı, müktesep hak kavramı ile birlikte incelemektedir. Yazara göre bir hakkın müktesep hak mı yoksa vazgeçilmez hak mı olduğunun tespiti ancak hakkın süjesinin kendi iradesi ile bu hakları kullanmaktan yoksun kalıp kalamayacağı sorusunun cevabı ile yapılabilir. Bununla birlikte bir hakkın tek sefere mahsus olarak kullanılmaması o haktan vazgeçildiği anlamına da gelmemektedir. Vazgeçme ile ifade edilmek istenen hakkın kullanımından önceden feragat edilmesidir, Kırca, İsmail/Şehirali Çelik, Feyzan Hayal/Manavgat, Çağlar (2016) Anonim Şirketler Hukuku C. 2/II - Genel Kurul Kararlarının Hükümsüzlügü, Ankara, Banka ve Ticaret Hukuku Enstitüsü, s. 28-29. Yazar, vazgeçilmez haklara aykırı GK kararlarının münferit yahut süreklilik arz edip etmediğine bakılmaksızın TTK m. 447/1.b uyarınca her halükarda butlanla sakat olması gerektiğini de ifade etmektedir, s. 74 . 
bireysel niteliğini hem paya bağlllı̆̆ını ifade eder ${ }^{41}$. Bu bağlamda örneğin pay üzerinde intifa hakkı bulunsa dahi pay sahibinin GK'ya katılması engellenemez ${ }^{42}$.

GK'ya katılma; oy hakkı, iptal davası açma, bilgi alma ve görüş bildirme, müzakerelere katılma gibi diğer birçok hakkın kaynağıdır. GK’ya katılım, oy hakkının varlığı şartına bağlanamaz ${ }^{43}$. Bu doğrultuda oydan yoksunluk hallerinde dahi pay sahibi yahut temsilcilerinin de GK'ya ve müzakerelere katılma hakları bulunmaktadır zira oy hakkını kullanamayacak olsa da pay sahibinin GK’ya katılmak suretiyle diğer birçok pay sahipliği hakkını kullanmasi engelleneme $z^{44}$.

TTK m. 494 uyarınca borsaya kote edilmemiş nama yazılı payların devri halinde pay sahipliği sıfatı ve haklar ancak devralanın şirkete başvurusu ve şirketin kabulü üzerine devralana geçecektir. İşte bu halde iktisap edilme tarihi ile şirketin devri tanıması arasında geçecek sürede payı devralan kimse oy hakkından yoksun pay sahibi olarak pay defterine yazılır ve söz konusu paylar GK'da temsil edilemez ${ }^{45}$. Öyleyse bu kişiler şirketçe tanınıncaya kadar GK'ya katılma hakkını da haiz olmayacaktır ${ }^{46}$. Aynı durum borsaya kote nama

41 Tekinalp, s. 312 .

$42 \mathrm{Bu}$ durum, daha ziyade pay sahibinin iptal davası açma hakkından ileri gelmektedir, Tekinalp, s. 312; Kendigelen, Abuzer (1994) Anonim Ortaklık Payı Üzerinde İntifa Hakkı, İstanbul, Beta, s. 326, dn. 550'de zikredilen yazarlar. Aksi yönde bkz. Kendigelen, (1994), s. 326 , dn. 548 ve 549 'da zikredilen yazarlar.

43 Moroğlu, Erdoğan (2017) Anonim Ortaklıkta Genel Kurul Kararlarının Hükümsüzlügü, 8. Baskı, İstanbul, On İki Levha, s.122.

44 Teoman, Ömer (1983) Anonim Ortaklıkta Pay Sahibinin Oy Hakkından Yoksunluğu, Ankara, Banka ve Ticaret Hukuku Enstitüsü, s. 173-174; Arslanlı, s. 25; Moroğlu, (2017) s. 122, dn. 199; Doğanay, s. 929; Poroy, Reha/Tekinalp, Ünal/Çamoğlu, Ersin (2019) Ortaklıklar Hukuku II, 14. Baskı, İstanbul, Vedat, N. 953; Kaya, s. 133. Oy hakkından yoksun kimselerin GK toplantısına katılamayacağı yönünde esas sözleşme hükmü geçersizdir, Yargitay TD., 4.3.1965, E. 64/3347, K. 727 (Teoman, (1983), s. 174, dn. 4).

45 Mülga Sermaye Piyasası Kanunu'nda yer bulan oydan yoksun pay kavramına, 6362 sayılı Sermaye Piyasası Kanunu ile yer verilmemiştir. Esasen TTK m. 494 ve 497'de zikredilen teknik anlamda oydan yoksun pay olmayıp, devrin GK'ca tanınması anına kadar mevcut payların GK'da temsil edilememesi halidir.

46 Tekinalp (Poroy/Çamoğlu), C. 2, N. 946. 
yazılı paylar bakımından da geçerli olacak ve bu paylar da GK'da temsil edilemeyecektir (TTK m. 497/3).

Oy hakkının donduğu hallerde ise GK'ya katılma ve ona bağlı hakların kullanımına gelince: Bilindiği üzere TTK'da oy hakkının donması iki halde mümkündür. İlk olarak, şirketler topluluğunda birbirlerinin paylarını iktisap ederek karşılıklı iştirak oluşturan sermaye şirketleri, iştirak konusu olan paylardan doğan toplam oy ve bedelsiz pay alma hakkı hariç olmak üzere diğer pay sahipliği haklarının sadece dörtte birini kullanabilir. Bu halde donmaya konu olmayan dörtte birlik pay oranına ilişkin hakların kullanımı bakımından pay sahibinin GK'ya katılımı gereklidir ${ }^{47}$. İkinci donma hali ise TTK m. 389'da düzenlenen şirketin kendi paylarını iktisabı halidir. Hükmün lafzı şirketin edindiği kendi paylarının "hiçbir pay sahipliği hakkı vermeyeceğini” ifade etmektedir. Sonuç olarak bu halde şirketin kendi GK’sına katılma hakkını haiz olmayacağı açıktır ${ }^{48}$.

GK'ya katılabilmek için, katılma hakkının belgelenmesi gerekir. Hangi pay sahiplerinin bu yetkiyi haiz olduğu, YK tarafından düzenlenen "hazır bulunanlar listesi”ne göre belirlenir ${ }^{49}$. Buna göre, hazır bulunanlar listesinde adı bulunan senede bağlanmamış payların, ilmühaberlerin, nama yazılı payların sahipleri ve 6362 sayılı Sermaye Piyasası Kanunu (“SPK”) m. 1350

47 Bu yönde bkz. Okutan Nilsson, Gül (2009) Türk Ticaret Kanunu Tasarısı'na Göre Şirketler Topluluğu Hukuku, İstanbul, On İki Levha, s. 200 vd. eTTK döneminde tüm pay sahipliği hakları donduğundan, ilgili pay sahibinin GK’ya katılımı kabul edilmemekte idi, Teoman, (1983), s. 174.

48 Hem TTK m. 201 hem m. 389 bakımından GK’ya katılma haklarının da donacağına ilişkin bkz. Tekinalp (Poroy/Çamoğlu), C. 2, N. 946.

49 Bahtiyar/Hamamcıoğlu'na göre, hazır bulunanlar listesi isimlendirmesi isabetli olmayıp hazırlanan liste, katılanları değil, katılma hakkı olan pay sahiplerini ortaya koymaktadır, s. 56. Teoman'a göre, hazır bulunanlar listesinin düzenlenme amacı, toplantıda hazır bulunan veya temsil olunan pay sahiplerinin adlarının ve sahip olunan payların adedi hakkında diğer ortakları bilgilendirmek ve katılma hakkına ilişkin itirazların ve alınan kararların geçerliliğinin denetimi için hukuki bir kaynak yaratmaktır, Teoman, Ömer (2012) “Anonim Ortaklık Genel Kurul Toplantısına İlişkin Hazirun Cetveli”, Tüm Makalelerim C. 1-2, 2. Baskı, İstanbul, On İki Levha, s.1015 vd.

50 TTK m. 415/2'de 2499 sayılı mülga Sermaye Piyasası Kanunu'nun 10/A maddesine atıf yapılmaktadır. Anılan düzenlemenin meri Kanun'da karşılı̆̆ 13. maddedir. 
uyarınca kayden izlenen pay sahipleri ${ }^{51}$ veyahut anılanların temsilcileri GK'ya katılır. Gerçek kişilerin kimlik göstermeleri, tüzel kişilerin temsilcilerinin vekâletname ibraz etmeleri şarttır (TTK m. 415/2). YK, SPK m. 13 uyarınca GK'ya katılabilecek kayden izlenen payların sahiplerine ilişkin çizelgeyi ise Merkezi Kayıt Kuruluşundan sağlar. (TTK m. 417/1). Senede bağlanmamış bulunan veya nama yazılı olan paylar ile ilmühaberler bakımından pay defterinde kayıtlı olan pay sahibi, hak sahibi kabul edilir (TTK m 417/2).

Hamiline yazılı pay senedi sahipleri, GK'nın toplantı gününden en geç bir gün önce bu senetlere zilyet olduklarını ispatlayarak giriş kartı alırlar ve bu kartları ibraz ederek GK toplantısına katılabilirler. Ancak, giriş kartının verilmesinden sonraki bir tarihte hamiline yazılı pay senedini devraldığını ispatlayan pay sahipleri de GK'ya katılabilirler (TTK m. 415/3).

İlgili hükümlere göre GK toplantısına katılma haklarının bulunduğunu gerekli vasıtalarla ispatlayamayan kişiler ile temsilcileri GK toplantısına alınmazlar. Ne var ki bu kişilerin GK’ya katılımı bizatihi alınan kararların iptalini gerektirmemektedir. TTK m. 446/1.b’ye göre alınan kararlar ancak yetkisiz katılanın, kararın alınmasına etkili olduğu hususunun ispatı ile mümkün olur ${ }^{52}$.

51 Kanun'da her ne kadar "kayden izlenen pay sahipleri” terimi kullanılsa da kayden izlenen, pay sahibi değil pay olduğundan bu ifade, "kayden izlenen payların sahipleri” olarak anlaşılmalıdır.

52 Moroğlu, (2017), s. 125-126. Burada etkili olmanın salt bir yeter sayı problemi olmadığı, anılan kimselerin toplantıya katılmaları halinde diğer pay sahiplerinin kararlarının şekillenmesine de etkili olabileceğinin ispatlanması halinde GK kararının iptali kabil olması gerektiği yönünde bkz. Moroğlu, (2017), s. 251. Kırca da hükümde bahsedilen "etki”nin aslında illiyet bağı olduğunu vurgulamakta; iptal yaptırımı bakımından ise niteliksel ve niceliksel (sayısal) olmak üzere ikili bir ayrıma gitmektedir. Niceliksel olarak yapılan inceleme sonucu, 446/1-b'de sayılan aykırılıklar sebebiyle iptal davası açamayanların sayısı, fiilen kullanılan olumsuz oyları aşıyorsa karar iptal edilmelidir. Öte yandan niteliksel hukuka aykırılığın tespitinde sayısal etkiye bakılmamalı, pay sahibinin davranışını etkileyen normatif illiyetin varlı̆̆ı araştırılmalıdır, Kırca/Şehirali Çelik/Manavgat, (2016), s. 152157. 


\section{Intifa Hakkı Sahipleri}

TTK m. 432/2'ye göre, bir payın üzerinde intifa hakkı bulunması hâlinde, aksi kararlaştırılmamışsa oy, intifa hakkı sahibi tarafından kullanılır ${ }^{53}$. Oy hakkı ve oy hakkına bağlı iptal davası açma gibi haklar ${ }^{54}$ intifa hakkı sahibine tanınmış olduğundan, intifa hakkı sahibinin GK'ya katılma yetkisi de bulunmaktadır. Bu yetkisini kullanırken intifa hakkı sahibinin pay sahibinin menfaatlerini gözetmesi ve hakkaniyet doğrultusunda hareket etmesi gereklidir. Aksi yönde hareket halinde intifa hakkı sahibi malike karşı sorumludur. $\mathrm{Bu}$ doğrultuda intifa hakkı sahibinin $\mathrm{GK}$ toplantısına katılmaması da malikin çıkarlarını zedeliyorsa intifa hakkı sahibinin malike karşı sorumluluğu doğar (TTK m. 432/2).

TTK m. 499/1'e göre, intifa hakkı sahiplerinin adı, soyadı, unvan ve adresleri de pay defterine kaydedilir. GK'ya katılmaya yetkili olanlar, pay defterine bakılarak saptanacağından bu kişiler de hazır bulunanlar listesinde yer alacaklardır. İntifa hakkı sahiplerinin bir sebeple pay defterine kaydının gerçekleşmemesi halinde hakkın kurulması için pay defterine kayıt

53 Payın bir bölümü üzerinde intifa hakkı bulunması durumunda Yargıtay, vermiş olduğu bir kararında, intifa hakkının var olmasını yeterli görerek payın hangi oranda intifa hakkına konu olduğunu araştırmamış, oy hakkının sahibinin intifa hakkı sahibi olduğu sonucuna varmıştır. Bkz. Yargitay 11. HD., 28.5.1981, E. 81/2243, K. 812678 [Tekinalp (Poroy/Çamoğlu), C. II, N. 972]. Kendigelen de, eTTK döneminde pay üzerindeki intifa hakkının yüzde elli ve altında olması halinde oy hakkının pay sahibine ait olması gerektiğini savunarak oy hakkının her halde intifa hakkı sahibine ait olduğu görüşüne karşı çıkmaktadır, (1994), s. 256. Kanaatimizce de, TTK m. 432/2 intifa hakkı sahibinin, pay sahibinin menfaatlerini hakkaniyete uygun bir şekilde göz önünde tutarak hareket etmesini düzenlediğinden payın tümü yahut büyük bölümü üzerinde intifa hakkı sahibi olan bir kimsenin sorumluluğu ile daha küçük oranda intifa hakkı bulunan bir kimsenin sorumluğu hakkaniyet gereği aynı ölçüde olmamalıdır.

54 İntifa hakkı sahibinin iptal davası açma hakkının olup olmadığı yönünde ayrıntılı bir inceleme için bkz. Teoman, Ömer (2012) “Anonim Ortaklıkta Paylar Üzerinde İntifa Hakkı Bulunması Durumunda Oy Hakkı Dışındaki Yönetim Haklarının Kimin Tarafından Kullanılacağı Sorunu”, Tüm Makalelerim C. 1-2, 2. Baskı, İstanbul, On İki Levha, s. 365 vd. Moroğlu, pay sahibi ile intifa hakkı sahibinin münferiden dava açmaya yetkili olduğunu, bu durumda bu kişiler arasında ihtiyari dava arkadaşlı̆̆ bulunduğunu ifade etmektedir, (2017), s. 270. 
zorunluluğu bulunmadığından ${ }^{55}$ bu kimselerin intifa hakkı sahibi olduklarını ispatlayıcı belgelerle GK toplantısına katılabilmeleri gerekir ${ }^{56}$. Aksi halde, bu kişilerin GK'ya katılımı haksız olarak engellendiğinden şartları oluşması durumunda TTK m. 446/1.b uyarınca ilgili GK'da alınan kararların iptali dava edilebilecektir.

Pay üzerinde intifa hakkı kurulmasına rağmen payın mülkiyeti pay sahibine ait olduğundan doktrinde, intifa hakkı sahibinin yanı sıra pay sahibinin de GK toplantısına katılabileceği, müzakerelere katılarak görüş bildirebileceği ifade edilmektedir, zira burada pay sahibinin şirkete ilişkin iş ve işlemlerle ilgili bilgi almasında hukuken korunmaya değer menfaati sürmektedir ${ }^{57}$.

\section{Rehin ve diğer hak sahipleri}

Rehin hakkı, hak sahibine yalnızca alacağı tahsil edemediğinde rehne konu malvarlı̆̆ı unsurunu paraya çevirme ve bu tutar ile alacağını tahsil

55 TTK m. 499/4 uyarınca, sadece pay defterinde kayıtlı bulunan kimse pay sahibi ve intifa hakkı sahibi olarak kabul edilir. Pay senetlerinin bağlamlı olması durumunda, bu sınırlama intifa hakkı kurulurken de geçerli olacaktır (TTK m. 492/2). Bu halde şirket, bağlı nama yazılı payların şirket onayıyla devredileceğini öngördüğünden devre (dolayısıyla intifa hakkı kurulmasına) onay verilmemesi halinde tüm haklar payın malikinde kalacaktır (TTK m. 494).

56 Pay üzerinde intifa hakkının kurulması için pay defterine kaydın kurucu olmadığı yönünde bkz. Narbay, Şafak (2003) Anonim Ortaklıkta Pay Defteri, Ankara, Seçkin, s. 68-69; Kendigelen, (1994), s. 105. İntifa hakkının kurulması bakımından değişik olasılıklar için bkz. Kendigelen, (1994), s. 77-101.

57 Moroğlu, (2017), s. 272. GK toplantısına katılımla payı üzerinde intifa hakkı bulunan pay sahibinin ayrıca bilgi alma, azınlık haklarını kullanma, GK kararlarının iptalini dava etme vb. hakları da sürmektedir, Kendigelen, (1994), s. 327-328; Tekinalp(Poroy/Çamoğlu), C. 2, N. 974. İntifa hakkı sahibinin iştirak ettiği bir GK toplantısında oy kullanma yetkisi aksi kararlaştırılmadıkça intifa hakkı sahibine ait olduğundan pay sahibinin karara olumsuz oy kullanma şartını sağlamasa da muhalefetini tutanağa geçirerek iptal davası açabileceği hakkında bkz. Moroğlu, (2017), s. 272-273. Oy hakkından yoksun pay sahibinin hukuki durumuna paralel olarak (TTK m. 436) oy hakkından bağımsız olarak iptal davası açılacağından pay sahibinin de iptal davası açabileceği yönünde bkz. Kendigelen, (1994), s. 307. 
yetkisi veren bir ayni haktır ${ }^{58}$. Pay üzerinde rehin hakkı bulunması durumunda oy hakkı kural olarak pay sahibine aittir. Ancak taraflar bunun aksini kararlaştırabilirler. Dolayısıyla, rehin hakkı sahibine sözleşme ile oy hakkının tanınması halinde bu kimselerin de GK'ya katılma hakkı bulunacağ kuşkusuzdur ${ }^{59}$.

Rehin hakkı sahibi, GK'ya katılıma hakkını haiz olduğunu belgelemek durumundadır. Zira TTK m. 427/2, hamiline yazılı pay senedini, rehin, hapis hakkı, saklama sözleşmesi veya kullanım ödüncü sözleşmesi ve benzeri sözleşmeler sebebiyle elde bulunduran kimsenin, pay sahipliği haklarını, ancak pay sahibi tarafından özel bir yazılı belge ile yetkilendirilmişse kullanabileceğini düzenlemektedir.

Bilindiği üzere hamiline yazılı pay senetlerinin devri ve diğer hukuki işlemlere konu olabilmesi için zilyetliğin devri yeterli olup başkaca bir işleme gerek bulunmamaktadır. Hamiline yazılı bir pay senedi üzerinde rehin hakkı, rehin cirosu ile tesis edilebileceği gibi doğrudan zilyetliğin geçirilmesiyle de kurulabilir. Bu halde hamiline yazılı senede zilyet olduğunu ispat ederek giriş kartı alan yahut hak sahipliğini sonradan ispat eden kişilerin GK’ya katılabileceklerini kabul etmek gerekir. Rehin hakkının, intifa hakkı gibi pay defterine kaydı da söz konusu olmadığından ayrıca bildirim yapılmadığı sürece şirketin, hamiline yazılı bir pay senedinde rehin hakkı bulunduğunu tespit edebilmesi mümkün olmayacaktır ${ }^{60}$. Bu sebeple, TTK m. 427/2'de

58 Oğuzman, Kemal/Seliçi, Özer/Oktay Özdemir Saibe (2017) Eşya Hukuku 20. Baskı, İstanbul, Vedat, N. 3176.

59 Çamoğlu (Poroy/Tekinalp), s. 486-487. Rehin hakkı sahibi ile pay üzerinde vedia yahut ariyet bulunması halinde bu kimselerin iptal davası açma hakkının bulunup bulunmadığını tartışan Moroğlu, soruyu olumsuz yanıtlamaktadır, (2017), s. 273-274. Ancak tabi ki, TTK m. 427/2'ye göre rehin, hapis hakkı, saklama sözleşmesi yahut kullanım ödüncü sözleşmesi ile pay üzerinde hak sahibi olan kişilere pay sahipliği haklarının kullanılabilmesi konusunda özel temsil yetkisi ya da vekâlet verilebilecektir.

60 Bu yönde bkz. Karamanlığlu, Argun (2016) Anonim Ortaklıkta Pay Sahibinin Genel Kurul Toplantısında Temsili, İstanbul, Vedat, s. 250. Hamiline yazılı pay senetlerinde rehin hakkı rehin cirosuyla da tesis edilebilir. Bu halde GK'ya katılmak isteyen rehin hakkı sahibinin bu hakkı senet metninden anlaşılacağından anılan kişinin GK'ya katılma hakkının varlığına ilişkin yetkiyi belgelendirmesi gerekecektir. Yılmaz’a göre, pay sahibi rehin sözleşmesini ibrazı yanında rehin hakkı tesis edilirken hamiline yazılı senedin noter onaylı 
aranan yazılı belgenin mevcudiyetinin araştırılması da söz konusu olmayacak, senede zilyet bulunan rehin hakkı sahibi bu şekilde GK toplantısına katılabilecektir ${ }^{61}$.

Tekinalp, hükmün düzenlenme amacının senede zilyet olan bir finansal kurumun, pay sahibi ile aralarındaki saklama, rehin vs. sözleşmesinde yer alan hükümler uyarınca pay sahipliği haklarını pay sahibinin bilgisi dışında kullanmasının önüne geçilmesi olarak ifade etmiştir ${ }^{62}$. Ne var ki yukarıda izah ettiğimiz sebeple bu düzenlemenin uygulamada amacını ne kadar gerçekleştireceği tartışmalıdır.

Rehin hakkı sahibine tanınan GK toplantısına katılma ve oy verme hakkı, rehin hakkı sahibi ile payın maliki arasında borçlar hukuku anlamında bir temsil yetkisi verilmesinden ibarettir. $\mathrm{Bu}$ anlamda rehin hakkını haiz kimsenin sahip olduğu hak, özünde GK'ya katılma ve oy kullanma hakkını içermediğinden, bu hak ancak bir borçlar hukuku sözleşmesi ile rehin hakkı sahibine tanınabilir. Kanun koyucu rehin hakkı sahibine tanınacak bu yetkinin, TTK m. 427/2 uyarınca ancak özel yazılı bir belge ile verileceğini öngördüğünden taraflar, bu belgeye oyun hangi yönde kullanılacağına ilişkin hükümler de koyabilirler ${ }^{63}$. Bu hükümlere aykırılık, tıpkı temsil ilişkisinde

bir örneğinin de ibrazı GK’ya katılım noktasında çıkabilecek sorunları ortadan kaldırması bakımından önemlidir, Yılmaz, Abdüssamet (2020) Anonim Ortaklık Payının Rehin ve Hapis Haklarına Konu Olması, İstanbul, On İki Levha, s. 135.

61 TTK m. 426/2 karşısında GK’ya katılım için zilyetliğe ek bir başka hususu talep hükmün lafzı ve amacıyla bağdaşmayacaktır. Nitelim hamiline yazılı senetlerin tedavülü kanun koyucu tarafindan kolaylaştırılmıştır. Örneğin TTK m. 415/4 Genel kurula katılma ve oy kullanma hakkının, pay sahibinin, payların sahibi olduğunu kanıtlayan belgeleri veya pay senetlerini şirkete bir kredi kuruluşuna veya başka bir yere depo edilmesi şartına bağlanamayacağının düzenlenmesi de bunu bir başka ispatıdır. Aynı durum nama yazılı pay senedini görünürde temlik cirosuyla devralan gizli rehin hakkı sahibi bakımından da geçerlidir, Yılmaz, s. 133-134.

62 Tekinalp (Poroy/Çamoğlu), C. 2, N. 975a.

63 Benzer şekilde borcu için payını rehneden pay sahibinin de oyunu rehnalanın talimatları doğrultusunda kullanacağına ilişkin bir oy sözleşmesi yapılması da mümkündür. Moroğlu bu durumu doktrinde sürekli nitelikte oy sözleşmesi olarak tanımlamıştır, Moroğlu, Erdoğan (2015) Oy Sözleşmeleri, 5. Baskı, İstanbul, Vedat, s. 41. 
olduğu gibi taraflar arasında borçlar hukukuna ilişkin bir talep gündeme getirebilirse de oyun geçerliliğine etki etmemelidir ${ }^{64}$.

\section{B. YÖNETIM KURULU ÜYELERİ}

Yukarıda da belirtildiği üzere, eTTK döneminde YK üyelerinin GK toplantısına katılmasının bir zorunluluk olup olmadığı konusunda kanunda bir açıklık bulunmamakta idi. Bu sebeple YK üyelerinin GK toplantılarına katılmayarak, pay sahiplerinin bilgi alma haklarını kullanılamaz duruma getirmesini eleştiren Teoman, hiç olmazsa bilançonun görüşüldüğü toplantılarda YK üyelerinin bizzat bulunma yükümlülüğü olduğunun kabulü gerektiğini ifade etmiştir ${ }^{65}$. Yazar, bu noktada kanundaki boşluğun bilinçsiz olduğunu kabul ederek, şirket ile YK üyelerinin arasındaki vekalet ilişkisi dolayısıyla YK üyelerinin GK toplantısına katılmalarının aynı zamanda kendileri açısından bir yükümlülük olduğunu belirtmiş̧iir ${ }^{66}$.

Anılan tartı̧ma, TTK m. 407/2 ile giderilmeye çalışılmış, yalnızca murahhas üyeler ile bir YK üyesinin GK toplantısina katılımı zorunlu tutulmuştur. Bu düzenleme ile YK üyelerinin tamamı için değil yalnızca bir YK üyesi için katılım hem hak hem bir yükümlülük olarak düzenlenmekte iken, kalan YK üyeleri için yalnızca GK toplantısına katılım ve görüş bildirme hakkı tanınmıştır ${ }^{67}$.

\section{PAY ÜZERINNDE HAK SAHİBİ OLAN KIMSELERIN TEMSILCILERI}

\section{Adi Temsilci}

Pay sahiplerinin ilke olarak GK'ya bizzat katılımı zorunlu olmadığından kendisini pay sahibi olan yahut olmayan bir temsilci aracılı̆̆ 1 ile temsil ettirmesi de mümkündür (TTK m. 425). Pay sahibinin temsiline ilişkin hükümler TTK m. 427 vd.'nda düzenlenmektedir. Kanunun sistematiğine

\footnotetext{
64 Tekinalp(Poroy/Çamoğlu), C. 2, N. 987d.

65 Teoman, (2012b), s. 225; Teoman, (2012a), s. 417.

66 Teoman, (2012b), s. 226; Teoman, (2012a), s. 417.

67 Bkz. I.a.3.
} 
bakıldığında bu hükümler, "Pay Sahibinin Kişisel Hakları” başlığı altında yer aldığından doktrinde, söz konusu hakkın "pay sahibinin temsil hakk»" adı altında vazgeçilmez bir kişisel pay sahipliği hakkı olarak değerlendirileceği ifade edilmektedir ${ }^{68}$. Oyun kullanılamaması sonucuna yol açacak şekilde temsil hakkını kısıtlayan yahut ortadan kaldıran esas sözleşme hükümleri geçersizdir ${ }^{69}$.

Temsil yetkisinin verilme şekli TTK m. 426/1 ile TTK m. 427/2 de gösterilmektedir. Buna göre, senede bağlanmamış paylardan, nama yazılı pay senetlerinden ve ilmühaberlerden doğan pay sahipliği haklarının temsilci aracılığı ile kullanılabilmesi için pay sahibinin temsilciyi yazılı olarak yetkilendirmesi gereklidir (TTK m. 426/1) ${ }^{70}$. Bu şekilde TTK m. 426/1, TBK m. 40 vd.'daki temsile ilişkin genel hükümlerdeki şekil serbestisinden sapmakta ve temsil yetkisinin verilmesini adi yazılı şekle tabi tutmaktadır. Bunun yanında, TTK m. 426/1, m. 427/2'nin aksine bu yetkinin ayrı bir belgede yer alması zorunluluğunu şart koşmamaktadır ${ }^{71}$. Yetkiyi verecek olan kişi ise hiç kuşkusuz pay defterine kayıtlı olan pay sahibidir. Yine de pay defterine kayıt kurucu olmayıp açıklayıcı nitelikte olduğundan, gerçekte pay sahibi olan kimseler de maddi anlamda hak sahipliklerini ispat ederek temsil yetkisi verebileceklerdir ${ }^{72}$.

GK’ya katılım ve oy kullanma hakkı bakımından alt temsilin mümkün olup olmayacağı da sorulabilir. TBK m. 506 uyarınca, temsilci, temsil yetkisini bizzat ifa etmekle yükümlü ise de temsil olunan tarafından bizzat yetki verildiği veya durumun zorunlu ya da teamülün mümkün kıldığı hâllerde

68 Karamanlığlu, s. 144; Bahtiyar, s. 171; Kırca (Şehirali Çelik/Manavgat), C. 2, s. 46; Bahtiyar/Hamamcioğlu, s. 58.

69 Bahtiyar/Hamamcioğlu, s. 58; Narbay, s. 214.

70 Yetkinin hangi toplantı için verildiği mutlaka belirtilmelidir, toplantı ertelendiği takdirde yeni bir yetkilendirme gerekir, Tekinalp (Poroy/Çamoğlu), C. 2, N. 979.

71 Çamoğlu (Poroy/Tekinalp), C. 1, N. 681c; Pulaşlı, C. 1, s. 961; Bahtiyar/Hamamcıŏlu, s. 59. Örneğin temsil yetkisi taraflar arasında yapılan bir sözleşmenin içeriğine de dahil olabilir, Karamanlığlu, s. 233.

72 Narbay, s. 215; Karamanlığlu, s. 235. Temsil yetkisi verenin maddi anlamda hak sahipliğini ispat eden temsilcinin GK'ya katılma ve oy kullanma talebini reddeden YK üyelerinin hukuki sorumluluğu söz konusudur, Narbay, s. 216. 
temsilci, temsil yetkisini başkasına devredebilir. Buna alt temsil adı verilir. Şirketler hukukunda da pay sahibinin açık rızası ile alt temsil mümkündür. Bu izin yetki belgesinde açıç̧a yer almalıdır. Bu durumda alt temsilci GK toplantısına katılma hakkını haiz olacaktır. Karamanlığlu'na göre GK'ya katılım hakkının varlığı bakımından sorun yaşanmaması için alt temsil yetkisinin yetki belgesinin zorunlu içeriğinden olduğunun kabulü gerekir ${ }^{73}$.

TTK, temsil yetkisinin verilmesi için yalnızca yazılı şekli gerekli ve yeterli saymakta iken BakTemYön m. 18/7'de gerek nama gerek hamiline yazılı pay senetlerine ilişkin verilecek temsil yetkisinin noter onaylı vekâletname ile olması yahut vekâletnameye vekâlet verenin imza beyanının eklenmesi şart koşulmuştur. BakTemYön m. 18/7’nin Kanun'da öngörülmeyen bir şekil şartı öngörmesi ve düzenlemenin normlar hiyerarşisine aykırı olması doktrinde eleştirilmişti ${ }^{74}$. Kanaatimizce, anılan düzenleme, TTK'da düzenlenen pay sahibinin temsiline ilişkin vazgeçilmez hakkın özüne aykırı olup, bu hakkı hükmün amacını aşar şekilde sınırlandırmaktadır. Nama yazılı pay senetleri açısından adi yazılı temsil yetkisinin varlığı temsilcinin GK'ya katılımı için yeterli olmalıdır ${ }^{75}$.

73 Karamanlığlu, s. 192.

74 Pulaşlı, temsil belgesindeki imzanın noter onaylı olmasının esas sözleşme ile de bir zorunluluk olarak öngörülemeyeceğini zira bu durumda oy hakkının özünün zarar gördügünü ve böyle bir maddenin kanuna aykırılık teşkil ettiğini ifade etmektedir, C. 1, s. 961; Tekinalp (Poroy/Çamoğlu), C. 2, N. 977; Bahtiyar/Hamamcıŏlu, s. 60. Hükmün normlar hiyerarşisi, TBK m. 12 ve m. 503'e aykırı olduğu yönünde bkz. Helvacı, Mehmet (1997) Anonim Şirket Genel Kurul Toplantıları ve Bu Toplantılarda Bulunacak Sanayi ve Ticaret Bakanlığı Komiserleri Hakkında Yönetmelik Gereği Ticaret Ortaklıklarının Özellikle Anonim Ortaklıkların Genel Kurullarının Yapılması, İstanbul, Beta, s. 47-49; Çamoğlu (Poroy/Tekinalp), C. 1, N. 681c; Karamanlığlu, s. 238.

75 Aykırılık durumunda GK'da alınan kararların batıl mı yoksa iptal edilebilir mi olduğu doktrinde tartışmalıdır. Kırca, münferit de olsa pay sahibinin kanundan kaynaklanan vazgeçilmez haklarını sınırlandıran veya ortadan kaldıran kararların TTK m. 447/1.a uyarınca batıl olduğu görüşündedir, Kırca(Şehirali Çelik/Manavgat), C. 2, s. 74. Moroğlu'na göre ise doğrudan mutlak emredici olup kamu düzenine ilişkin bulunan GK kararları ile nispi emredici kuralların ilerisi için de kaldırılması sonucunu doğuran genel nitelikte kararlar batıl olup, münferit olarak nispi emredici kullara aykırı alınan GK kararları iptal edilebilirdir, (2017), s. 63 vd. 
Hamiline yazılı pay senetleri bakımından kanun koyucunun amacı bu senetlerin içerdiği hakkın kullanımının kolaylaştırılmasıdır. Bunun bir örneğini, TTK m. 415/4 hükmünde görmek mümkündür. eTTK döneminden farklı olarak TTK m. 415/4, GK'ya katılım ve oy hakkı kullanımı bakımından pay senetlerinin şirkete, bir kredi kuruluşuna veya başka bir yere depo edilmesinin şart koşulamayacağını düzenlemektedir. Buna paralel şekilde ve senedin zilyetliğinin mevcudiyetini yeterli gören TTK m. 426/2'nin varlığ1 karşısında hamiline yazılı senedi rehin hakkı dolayısıyla elinde bulunduran kimsenin pay sahipliği haklarını kullanmasının ek bir taleple zorlaştırılmaması icap eder. Noter onaylı vekâletname ibraz edilmediği gerekçesiyle temsilcinin GK'ya alınmaması halinde pay sahibinin, GK'da alınan kararların iptalini dava edebilmesi gerekir ${ }^{76}$.

Anılan hüküm, rehin, hapis hakkı ile saklama ve kullanım ödüncü sözleşmelerinin varlığında dahi GK’ya katılma ve oy kullanma hakkının pay sahibinde olduğu gerçeğinden hareketle, hamiline yazılı pay senedine zilyet olan hak sahibinin mülkiyet karinesinden faydalanarak bu hakları kendi adına kullanamayacağının altını çizmektedir. Temsil yetkisinin verilmesine dair şekli düzenlemeler pay sahibi ile temsilci arasındaki iç ilişkiye yönelik olup, temsilcinin toplantıya katılabilmesi için yalnızca zilyetliğin anonim şirket bakımından yeterli olması gerekir ${ }^{77}$.

GK'da pay sahibini temsil edecek temsilci, tam ehliyetli olmalıdır. Ayrıca farklı gündem maddelerine ilişkin konularda oy kullanma hakkını haiz birden çok temsilci de GK toplantısında bulunabilir ${ }^{78}$. Buna karşın birden çok temsilci atanması durumunda BakTemYön m. 18/8 uyarınca, oy bunlardan yalnızca birisi tarafından kullanabilir ve yetki belgesinde hangi temsilcinin oy

76 Karamanlıŏ̆lu'na göre, TTK m. 426/1'de senede bağlanmamış paylardan, nama yazılı pay senetlerinden ve ilmühaberlerden bahsedilmesine karşın hamiline yazılı pay senetlerinin kapsama dahil edilmemesi bilinçli bir tercihtir, zira TTK m. 427/2 saklı kalmak üzere, hamiline yazılı paylarda temsil yetkisi verilmesi için herhangi bir şekil şartı öngörülmemektedir, s. 251.

77 Narbay, s. 216; Karamanlığlu, s. 249-250.

78 Karamanlığlu, s. 228. 
kullanmaya yetkili olduğu gösterilir ${ }^{79}$. Ayrıca BakTemYön m. 18/9'a göre, durumun belgelendirilmesi şartı ile kanuni temsilci olan veli yahut vasinin de GK'ya katılma hakkı vardır.

TTK m. 432'ye göre bir pay, birden çok kişinin ortak mülkiyetindeyse bunlar içlerinden birini veya üçüncü bir kişiyi, GK'da paydan doğan haklarını kullanması için temsilci olarak atayabilirler. Bahtiyar/Hamamcıoğlu; haklı olarak, kanunun lafzından bu atamanın ihtiyari olduğunun anlaşıldığını, ne var ki pay üzerinde ortak mülkiyet bulunması halinde bir müşterek temsilcinin atanmasının zorunlu olduğunu ifade etmektedirler ${ }^{80}$.

Kayden izlenen paylara ilişkin temsil yetkisi SPK m. 30/2 ile "Vekaleten Oy Kullanılması ve Çağrı Yoluyla Vekalet Toplanmasına” ilişkin SPK II-30.1 sayılı Tebliğ hükümleri uyarınca verilir. Buna göre, hamiline ya da nama olması fark etmeksizin halka açık ortaklıklarda vekâletname ile temsil, en az Tebliğ Ekinde yer alan bilgileri içeren vekâletname formlarının kullanılmasıyla mümkündür $(\mathrm{m} \text {. 6/1 })^{81}$. Oy hakkını haiz pay sahipleri elektronik GK sistemi vasıtasıyla veya fiziki olarak düzenlenen vekâletname formunda yer alan imzayı onaylattırarak veya noter huzurunda düzenlenmiş

79 Birden çok temsilci bulunması halinde toplantı başkanlığının oy hakkını haiz olmayan temsilcileri GK’ya almamasının pay sahibinin toplantıya katılma hakkının ihlali olmadığı yönünde bkz. Bilgili/Demirkapı, s. 322.

80 Bahtiyar/Hamamcıoğlu, s. 61. Pay üzerinde birden fazla malikin bulunması halinde TTK m. 432/I'in, genel kurulda paydan doğan hakların kullanılması için temsilci atanabileceğini öngördüğü; eTTK m. 373/II'ün ise, bu halde hakların temsilci ile kullanımının zorunlu olduğu anlamını çıkarak şekilde "ancak bir temsilci marifetiyle rey haklarını kullanabilirler" düzenlemesini haiz olduğu; Gerekçe'de, hükmün, m. 373/II'nin tekrarı olduğu ifadesi ile yetinildiği ve ifade farklılığına ilişkin bir açıklama yapılmadığı; bu sebeple doktrinin, payın birden fazla malikinin bulunması halinde, paya ilişkin hakların genel kurulda yalnızca bir temsilci aracılığıyla kullanılabileceği kanaatinde olup, hükmün önceki ve şimdiki versiyonu arasındaki farklılık dikkate alınmaksızın bu kanaatin muhafaza edildiği; oysa TTK m. 432/I'den böyle bir sonuç çıarmanın mümkün olmadığı yönünde bkz. Sarıkaya, Sinan (2019) Şirket Birleşmelerinde Ortakların Dava Yoluyla Korunması, İstanbul, Vedat, s. 276.

81 Vekaletname formunda vekil tayin edilen kişinin ad, soyad/ticaret unvanı ve T.C. Kimlik numarası/ticaret sicili ve numarası/vergi kimlik numarası ile Merkezi Sicil Kayıt Sistemi (MERSİS) numarasının açıkça belirtilmesi ve yabancı uyruklu vekiller için anılan bilgilerin varsa muadillerinin sunulması zorunludur. 
imza beyanını imzalı vekâletname formuna eklemek suretiyle vekil tayin ederler (m. 8).

TTK m. 427/2'de, adi temsilcinin pay sahibinden talimat almasi zorunluluğu düzenlenmemiştir. Yine de talimatın varlığ halinde temsilcinin, temsil edilenin talimatlarına uyması gerekir. Bu talimat her bir gündem maddesine ilişkin yahut genel olarak verilebilir ${ }^{82}$. Talimata aykırılık oyu geçersiz kılmaz yalnızca temsil edilene karşı sorumluluk söz konusu olur (TTK m.427/1).

\section{Tevdi Eden Temsilcisi}

Tevdi eden temsilcisi (TTK m. 429) ${ }^{83}$, adi temsilci ile birlikte bireysel temsilcilerin diğer bir türü olup ${ }^{84}$, kendisine bir hukuki ilişki sebebiyle devredilmiş bulunan pay yahut pay senetlerinden doğan GK’ya katılım, oy kullanma haklarının özel bir yetkilendirme ile kullanımının devredildiği kimselerdir ${ }^{85}$. Pay sahibinin, pay senetlerini saklamak üzere bankalara, yönetilmek üzere portföy danı̧̧manlarına, yatırım yöneticilerine, saklama kuruluşlarına, rehin alacaklısına, aracı kurumlara ve avukatlara tevdi etmesi

82 Çamoğlu (Poroy/Tekinalp), C. 1, N. 681c; Karamanlığlu, s. 438.

83 Pulaşl, tevdi eden temsilcisi ifadesinin, kimin temsil edildiğinin tam olarak anlaşılmaması sebebiyle tevdi temsilcisi olması gerektiğini ifade etmektedir. Nitekim İsviçre ve Alman hukukunda yer alan "Depotvertreter" ifadesinin tam karşllığ da tevdi temsilcisidir, C. 1, s. 967, dn. 381.

847099 sayılı Kanunla yapılan değişiklikten önce temsil, bireysel ve kurumsal temsil olarak ikiye ayrılmakta; bireysel temsil türleri adi temsilci ile tevdi eden temsilcisi iken kurumsal temsilci olarak organın temsilcisi, bağımsız temsilci ve kurumsal temsilci düzenlenmekte idi. Ne var ki 10.3.2018 tarihli RG’de yayımlanan 7099 sayılı Kanun ile TTK’nın “Organın Temsilcisi, Bağımsız Temsilci ve Kurumsal Temsilci” başlı̆̆ını taşıyan 428. maddesi ile "Bildirge" başlıklı 430. ve "Bildirim" başlıklı 431. maddeleri yürürlükten kaldırılmıștır. Organın temsilcisi ve bağımsız temsilci hakkında ayrıntılı bir çalışma için bkz. Ayan, Özge (2012) "6102 sayllı Türk Ticaret Kanunun 428 Maddesinde Düzenlenen Organın Temsilcisi ve Bağımsız Temsilci”, Gazi Üniversitesi Hukuk Fakültesi Dergisi C. 16, S. 3, s. 7 vd.

Çamoğlu (Poroy/Tekinalp), C. 1, N. 681d. Tevdi, kural olarak GK'ya katılma ve oy hakkı vermemekle birlikte tevdi olunanlar ancak kendilerine pay sahibince özel yetki verilmişse bu hakları kullanabilirler, Kendigelen, Abuzer (2012) Türk Ticaret Kanunu Değişiklikler, Yenilikler ve İlk Tespitler, 2. Baskı, İstanbul, On İki Levha, s. 33; Bahtiyar (2020), s. 174; Bahtiyar/Hamamcioğlu, s. 63. 
mümkündür ${ }^{86}$. Kimlerin tevdi eden temsilcisi olabileceği BakTemYön m. 44'te yer almaktadır. Tevdi olunan kişiler, bağlı olacakları esas ve usuller ve temsil belgesinin içeriği Ticaret Bakanlığı'nca bir yönetmelikle ${ }^{87}$ düzenlenir (TTK m. 429/3).

BakTemYön m. 45’e göre, GK toplantısına katılma ve oy hakkının, tevdi edilen tarafından kullanılabilmesi için, taraflar arasındaki sözleşmede bu hususta açık bir hükmün yer alması veya BakTemYön Ek-6'da yer alan örnekteki içeriğe uygun şekilde düzenlenecek temsil belgesinin verilmesi zorunludur. Dolayısıyla burada hamiline yazılı pay senetleri bakımından TTK m. 427/2'de aranan ayrı bir yazılı belge şartının aranmadığı görülmektedir. Kanaatimizce, tevdi eden temsilcisi esasen TTK m. 427/2'ye göre kendisine saklama sözleşmesi uyarınca pay senedini elde bulundurma hakkı verilen kişi olduğundan, temsil yetkisinin verilme şekli ve hukuki sonuçlarının tevdi eden temsilcisine de uygulanması gerektiği sonucuna varılmalıdır. $\mathrm{Bu}$ nedenle, normlar hiyerarşisine aykırı BakTemYön m. 45'in değil, TTK m. 427/2 hükmünün tatbik edilmesi gerekmektedir ${ }^{88}$.

TTK m. 429/1 ve BakTemYön m. 46'ya göre, tevdi olunan, nasıl hareket etmesi gerektiği konusunda talimat almak için, her GK toplantısından önce, tevdi edene başvurmak zorundadır. Zamanında istenmiş olup da talimat alınamamışsa, tevdi edilen kişi, katılma ve oy haklarını, tevdi edenin genel talimatı uyarınca kullanır; böyle bir talimatın yokluğu hâlinde oy, YK'nın yaptığı öneriler ${ }^{89}$ yönünde verilir (TTK m. 429/2).

$\mathrm{Ne}$ var ki tevdi eden temsilcisinin pay sahibinin talimatına yahut YK üyelerinin önerilerine uygun hareket etmemesi halinde nasıl bir hukuki sonucun meydana geleceği konusunda hükümde bir açıklık

\footnotetext{
TTK m. 429 gerekçesi.

87 Tevdi olunan kişiler, bağlı olacakları esas ve usuller ve temsil belgesinin içeriği BakTemYön m. 44 ila 47 arasında düzenlenmektedir.

88 Bu yönde bkz. Karamanlığlu, s. 253.

89 Tevdi eden temsilcisinin hiç talimat almadığı hallerde oyunu dilediği yönde kullanabileceği görüşü için bkz. Özdemir, Türkay/Yiğit, İlhan (2007) Anonim Şirket Genel Kurullarında Pay Sahibinin Temsili ve Türk Ticaret Kanunu Tasarısı, Prof. Dr. Hüseyin Ülgen'e Armağan C.1, İstanbul, s. 461.
} 
bulunmamaktadır" ${ }^{90}$ Kendigelen, gerekçede hükmün "sosyal politika ile doğrudan ilgili emredici bir hüküm” olduğunun belirtilmesi nedeniyle talimata aykırı olarak oy kullanılması halinde TTK m. 427/1'in uygulanması sonucu oyun geçersiz sayılmaması gerektiğini; ancak aynı saptamanın talimat yokluğu yahut YK’nın önerilerine aykırı oy kullanılması ihtimalinde yapılamayacağını; aksi halde GK'da alınan kararların iptali kabil olabileceğini belirtmektedir ${ }^{91}$.

\section{GK’YA KATILABİLECEK DİĞER KİŞİLER}

TTK'nın 407. maddesinde zikredilen pay sahipleri, temsilcileri, murahhas üyeler, YK üyeleri ve denetçiler dışında, GK’ya katılma hakkı bulunan başkaca kimseler olup olmadığı gerek Türk gerek Alman doktrininde tartışma konusu olmuştur ${ }^{92}$. Uygulamada şirketin veya pay sahiplerinin avukatlarının, muhasebecilerinin, mali müşavirlerinin toplantıya katıldıkları sıklıkla gözlemlenmektedir ${ }^{93}$.

TTK m. 407 hükmünün gerekçesinde GK’ya katılma hakkının hükümde zikredilen kişilerden başkalarına tanınmasının "ratio legis”e uygun düşmediği ifade edilmektedir ${ }^{94}$. Konu hakkında detaylı bir çalışma kaleme alan Teoman, GK toplantısına dinleyicilerin katılıp katılamayacağını, bu konuda karar vermeye yetkili olan merciin kim olduğunu tartışmıştır. Konuyu eTTK döneminde ele alan yazar, bu hususta açık bir esas sözleşme hükmünün bulunması durumunda dinleyicilerin de GK toplantısına katılabileceğini ifade etmiştir ${ }^{95}$. Yazar, esas sözleşmede açık bir hüküm bulunmaması halinde de dinleyicilerin GK'ya katılabilmesini olanaklı görmekte, GK'nın pay sahipleri ve YK üyelerinden oluşan kapalı bir organ konumunda olmasının basın mensupları gibi dinleyicilerin katılımına engel oluşturmayacağını

\footnotetext{
90 Bahtiyar/Hamamcioğlu, s. 64.

91 Kendigelen (2012), s. 332.

92 İlgili tartışmalar için bkz. Teoman, Ömer (2012) “Anonim Ortaklık Genel Kurul Toplantılarına Dinleyicilerin Katılması", Tüm Makalelerim C. 1-2, İstanbul, On İki Levha, s. 247.

93 Pulaşlı, C. 1, s. 921; Bahtiyar/Hamamcıoğlu, s. 79.

94 TTK m. 407 gerekçesi.

95 Teoman (2012e), s. 247.
} 
belirtmektedir. Bu halde dinleyicilerin GK’ya alınıp alınmayacağı konusunda yetkili kişi GK başkanıdır (TTK m. 419) ${ }^{96}$.

TTK döneminde ise bu husus "Emredici Hükümler" başlıklı m. 340 kapsamında değerlendirilmektedir ${ }^{97}$. Buna göre doktrinde, esas sözleşme ile dinleyicilere de GK'ya katılma hakkı öngörülmesinin, TTK m. 340’ın varlığ 1 karşısında şüpheli olduğunu savunanların yanında ${ }^{98}$; esas sözleşmede bu yönde bir hükmün bulunabileceğini ve bu hususun emredici hükümler ilkesi ile çelişki yaratmayacağını ifade eden yazarlar da bulunmaktadır ${ }^{99}$. Bu yazarlara göre durumun esas sözleşme ile çözüme kavuşturulmaması halinde ise toplantı başkanı yahut GK'nın alacağı bir kararla dinleyicilerin GK'ya katılımı sorunu çözümlenebilecektir ${ }^{100}$.

Dinleyicilerin GK'ya katılımları konusunda BakTemYön ekinde yer alan "Toplantı Yerine Giriş ve Hazırlıklar” başlıklı m. 5’e göre de, toplantı başkanlığına seçilecek veya görevlendirilecek diğer kişilerin toplantıya girebileceği belirtilmektedir. Buna göre, şirketin diğer yöneticileri, çalışanları, misafirler, ses ve görüntü alma teknisyenleri, basın mensupları gibi kişilerin de toplantı yerine girmesi öngörülüyorsa bu durum ayrıca İç Yönerge'de (TTK m. 419/2) belirtilmelidir ${ }^{101}$. görüşündedir, Tekinalp (Poroy/Çamoğlu), C. 2, N. 949. Emredici hükümler hakkında monografik bir çalışma olarak bkz. Karasu, Rauf (2015)
Anonim Şirketlerde Emredici Hükümler İlkesi, 2. Baskı, Ankara, Yetkin.

99 Pulaşlı, C. 1, s. 921; Bahtiyar/Hamamcioğlu, s. 83.

00 Pulaşlı, C. 1, s. 921; İmregün, s. 129.

101 Moroğlu ve Pulaşlı ya göre, dinleyicilerin toplantıya alınması yahut alınmaması tek başına GK'da alınan kararların geçerliliğine etki etmez. Kararın iptali ancak bu kimselerin kararın alınmasında bir şekilde etkili olduklarının ispatı ile mümkün olacaktır, Moroğlu (2017), s. 135; Pulaşlı, C. 1, s. 921. 


\section{GK’YA KATILMAMANIN HUKUKİ SONUÇLARI}

TTK m. 407, GK'ya katılması zorunlu bulunan kimseler ile GK'ya katılmaya yetkili olan kişileri açıkça hükme bağlamasına karşın; katılımı bir yükümlülük olan kişilerin GK toplantısına iştirak etmemeleri halinde yaptırımının ne olacağı hususunda suskundur ${ }^{102}$.

İfade ediliş şekli, hükmün emredici olduğu izlenimi uyandırmakta ise de madde gerekçesi incelendiğinde, murahhas üyelerle en az bir YK üyesi ve denetçinin GK’ya katılımının bir zorunluluk olduğu ancak bu yükümlülüğe aykırı hareket edilmesinin GK'da alınan kararların geçerliliğini etkilemeyeceği ifade edilmektedir ${ }^{103}$. Hükmün lafzı ile gerekçe arasındaki bu uyumsuzluk, yükümlülüğe aykırı hareketin hukuki sonuçları hususunda tartışmalara gebedir. Aşağıda GK toplantısına katılma yükümlülüğüne aykırılığın yaptırımları ilgili görüşler ve kanaatimiz, murahhas üyeler ile denetçi ve bakanlık temsilcisi bakımından ayrı ayrı ele alınacaktır.

\section{A. MURAHHAS ÜYELER VE DENETÇINIIN GK TOPLANTISINA KATILMAMASI HALINDE ALINAN KARARLARIN YAPTIRIMI}

İkincil düzenlemelere bakıldığında tartışmaların özellikle KomY’nin yürürlükte olduğu dönemde ön plana çıtığı görülmektedir. Zira burada olağan GK toplantılarında YK üyeleri ile denetçilerden en az birisinin toplantıda hazır bulunması bir zorunluluk olarak öngörülmekte (KomY m. 20/2); aksi halde komiserin toplantının açılmamasına karar vereceği düzenlenmekte idi (KomY m. 31). eTTK'da, anılan kişilerin GK toplantısına katılım zorunluğuna ilişkin herhangi bir hüküm bulunmazken; Yönetmelik maddesi ile komisere toplantının açılmasına engel olma yetkisi verilmesi doktrinde, haklı olarak, eleştirilmekte idi ${ }^{104}$.

102 Moroğlu, Erdoğan (2012) 6102 sayılı Türk Ticaret Kanunu Değerlendirme ve Öneriler, 7. Baskı, İstanbul, On İki Levha, s. 209; Teoman, (2012b), s. 238.

103 TTK m. 407/2 gerekçesi. Kendigelen, ifade tarzının farklı yorumlara sebebiyet verebileceği gerekçesiyle hükmü eleştirmektedir, (2012), s. 306.

104 Helvacı, s. 42-46. Yaptırımın yerinde olmadığı ve komiserin görevi ile bağdaşmadığ 1 yönünde bkz. Teoman, (2012b), s. 230; Bahtiyar, Mehmet (2007) “Anonim Ortaklıkta Denetçilerin Rapor Hazırlamamaları ve Olağan Genel Kurul Toplantısına Katılmamaları 
Hâlihazırda yürürlükte olan BakTemYön m. 17, GK toplantılarında murahhas üyeler ile en az bir YK üyesinin hazır bulunmasının şart olduğunu; diğer YK üyelerinin de GK toplantısına katılabileceğini, ayrıca denetime tabi olan şirketlerin GK toplantılarında denetçinin de hazır bulunması gerektiğini düzenleyerek ilgili TTK hükmünü tekrar etmekte; bakanlık temsilcisinin görevleri arasında toplantıya katılması zorunlu olan kişilerin katılmaması durumunda toplantının açılmamasına karar verme yetkisine yer verilmemektedir. Ayrıca “Toplantının Yapılamaması” başlıklı m. 27'de ise yalnızca, gerektiği halde Bakanlık temsilcisi bulunmamasının toplantının yapılmasına engel olacağ 1 ifade edilmektedir.

eTTK ve KomY'nin yürürlükte olduğu dönemde katılması zorunlu kimselerin GK’ya katılmamasının hukuki sonuçlarını tartışan Kaya, konuyu bilgi alma hakkı bakımından değerlendirmektedir. Yazara göre, denetçiler ve YK üyeleri bilgi verme yükümlüsüdürler ve pay sahipleri bilgi alma haklarını GK'da kullanırlar ${ }^{105}$. eTTK'da denetçilerin bu yükümü açıkça zikredilmektedir. Zira yükümlülügün asıl muhatabı denetçilerdir ${ }^{106}$. Bu sebeplerdir ki denetçilerin GK'ya katılmaması halinde yeteri kadar bilgi sahibi olamadığını ifade eden pay sahibinin, bu hususu toplantı tutanağına kaydettirerek iptal davası açabilmesi gerekir ${ }^{107}$. YK üyeleri açısından da konuyu ele alan yazar, kanunun YK’ya GK'nın toplanması ile ilgili vermiş olduğu ödevler ve YK’nın da geniş anlamda bilgi verme yükümlüsü olması karşısında, YK üyelerinin de GK toplantısına katılmasının bir zorunluluk olduğunu ve katılmama halinde somut gündem maddesi ile ilgili iptal davası açılabileceğini ifade etmiştir ${ }^{108}$.

Teoman'a göre, toplantıya katılma yükümlülügüne aykırılık tek başına GK kararlarının geçerliliğine etki etmez, bu bir düzen hükmüdür. Yine de pay

Nedeniyle Komiserin Toplantıyı Açamamasının Sonuçları (Somut Bir Olaya İlişkin Notlar)", Maltepe Üniversitesi Hukuk Fakültesi Dergisi, Prof. Dr. Aydın Aybay’a Armağan, s. 374; Alışkan, Murat (2007) Türk Ticaret Kanunu'na Göre Sanayi ve Ticaret Bakanlı̆̆ı'nın Anonim Şirketleri Denetlemesi ve İlgili Fesih Davaları, İstanbul, Legal, s. 110.

105 Kaya, s. 169.

106 Kaya, s. 170.

107 Kaya, s. 172.

108 Kaya, s. 185. 
sahipleri bilgi alma haklarını gereği gibi kullanamadıklarını ileri sürmek suretiyle iptal davası açabilmelidirler ${ }^{109}$. Aynı zamanda bu yükümlülüğün ihlali, murahhaslar ile YK üyeleri ve denetçilerin sorumluluğuna da yol açabilmelidir ${ }^{110}$.

Moroğlu, Tekinalp, Bahtiyar ve Bilgili/Demirkapi'ya göre, kanunen katılması zorunlu olan kimselerin GK toplantısına katılmamalarının yaptırımının kanunda gösterilmemesi ve gerekçede bu hükmün bir düzen hükmü olduğunun ifade edilmesi karşısında alınan kararların iptali söz konusu olmayıp, bu durum olsa olsa GK'ya katılmayan YK üyeleri ve denetçilerin sorumluluğuna yol açabilir ${ }^{111}$.

Pulaşlı, murahhas üyeler ile en az bir YK üyesi ve denetçinin GK toplantısında hazır olmamasının doğrudan toplantının ve alınan kararın geçerliliğini etkilemeyeceğini ifade etmektedir. Yazara göre, gündemin müzakeresine geçilmeden önce, pay sahiplerinden birinin murahhas üyeler ile en az bir YK üyesinin GK toplantısında bulunmamasına yönelik bir itirazının bulunması ve bu itirazın tutanağa geçirilmesi şartıyla GK'da anılan kararların iptal edilebilmesi gerekir. Zira bu kimselerin toplantıda bulunmaması pay sahiplerinin bilgi alma hakkının ihlalidir ve mutlak bir iptal sebebi teşkil eder $^{112}$.

Denetçilerin de GK toplantısında hazır bulunmasının şart olduğunu belirten Pulaşlı, denetçinin özellikle olağan GK toplantılarına katılması

109 Teoman, (2012b), s. 238. Orbay Ortaç/Al Kılıç'a göre de yalnızca ilgililerin GK'ya katılmaması sebebiyle pay sahibinin vazgeçilemez nitelikteki bilgi alma hakkının ihlal edildiği durumlarda ilgili madde ve bununla bağlantılı gündem maddeleri bakımından karara muhalif kalarak ve bu muhalefetini tutanağa geçirerek iptal edilebilirlik yaptırımı kabul edilmelidir. Yazarlar, toplantıya katılmama halinde ise 446/1-b hükmünün işletilemeyeceği kanaatindedir, s. 230.

110 Teoman, (2012b), s. 238. Ayrıca yükümlülüğe aykırı hareket azil için haklı bir sebep de teşkil edecektir, Bahtiyar/Hamamcıoğlu, s. 75. YK üyelerine karşı açllacak olan sorumluluk davasında yükümlülüğün en az bir YK üyesine getirilmiş olması, diğer YK üyelerinin sorumluluğuna gidilemeyeceği anlamına gelmez. Bu durumda dava tüm YK üyelerine yöneltilecektir, Teoman, (2012b), s. 235.

111 Moroğlu (2017), s. 131-132; Tekinalp, s. 259; Bilgili/Demirkapı, s. 299.

112 Pulaşlı, C. 1, s. 919. 
gerektiğini, bu katılım zorunluluğunun İsvBK düzenlenmesinde olduğu gibi alınacak bir GK kararı ile de kaldırılamayacağını belirtmektedir. Bu sebeple, denetçinin GK'da hazır bulunmaması halinde GK'nın finansal tabloların tasdiki ve bilanço karının kullanımına ilişkin GK kararları iptali kabildir ${ }^{113}$.

Çamoğlu'na göre ise TTK’nın 407. maddesinin ikinci ve üçüncü fikraları emredici nitelikte olduğundan GK toplantısına katılması zorunlu olan kişilerden yoksun bir GK toplantısında alınan kararlar batıldır ${ }^{114}$.

Konuyu son dönemde ele alan Kendigelen/Çonkar'a göre, mehaz kanunlardaki düzenlemeler ${ }^{115}$, hukuk güvenliği ve butlanın ikincilliği prensibi dikkate alındığında hükmün yaptırımının yokluk, butlan yahut her halükarda iptal edilebilirlik olmaması gerekir. Alınan kararın bilgi alma hakkı ile doğrudan bağlantılı olması halinde ise yaptırımın iptal edilebilirlik olup olmayacağı değerlendirilebilir ${ }^{116}$. Yazarlar TTK m. 407’ye aykırılığın kategorik bir iptal sebebi olmasına gerek bulunmadığını nitekim önemli olan hususun bilginin kimin tarafından verildiği değil, somut olayda bilgi alma hakkının kullanılıp kullanılamadığı olduğunun altını çizmekte; bu sebeple TTK m.

113 Pulaşli, C. 1, s. 919.

114 Çamoğlu (Poroy/Tekinalp), C. 1, N. 680. Yazar, her ne kadar toplantının batıl olduğunu ifade etse de kanaatimizce toplantıda alınan kararların butlanından bahsetmek daha isabetli olacaktır. Yazar, aynı eserin 2013 basısında toplantının geçersizliğinden söz etmekte fakat bu geçersizliğin yaptırımını belirtmemektedir. Hükmün ikinci ve üçüncü fikrasının emredici olması, bu fikralarda bakanlı temsilcisinin de zikredilmesi ve Bakanlık temsilcisinin bulunmadığı toplantılarda alınan kararların genellikle yoklukla malul olmasından yola çıkarak Kendigelen/Çonkar, yazarın yokluk görüşünü benimsediği kanaatine varmışlardır. Kendigelen, Abuzer/Çonkar, Halil (2019) "Genel Kurula İlişkin Uygulamada Karşılaşılan İki Güncel Sorun”, Prof. Dr. Sabih Arkan’a Armağan, s. 679. Aynı eserin son basısında ise Çamoğlu, açıkça hükme aykırılığın yaptırımının butlan olduğunu belirtmiştir.

115 Örneğin, Alman hukukunda YK üyesinin GK’ya katılmaması halinde haklı sebeple azli yahut sorumluluğu gündeme gelirken; denetçinin toplantıya katılma yükümlülüğü yalnızca bilançonun onaylanması kararının GK’ya bırakıldığı hallerde mevcut olup bu yükümlülüğe aykırılık yalnızca bilançonun onaylanmasına ilişkin GK kararının iptaline neden olmaktadır, Kendigelen/Çonkar, s. 683.

116 Kendigelen/Çonkar, s. 684-685. 
407’ye aykırllğı̆n bir sorumluluk yahut haklı sebeple azil nedeni olacağını belirtmektedirler ${ }^{117}$.

\section{B. BAKANLIK TEMSILCISINININ GK TOPLANTISINA KATILMAMASI HALINDE ALINAN KARARLARIN YAPTIRIMI}

Anonim şirket GK toplantılarına katılması bir zorunluluk olarak öngörülen diğer grup ise Bakanlık temsilcisidir. Bu zorunluluk hem TTK $\mathrm{m}$. 407/3 hem de BakTemYön m. 32'de düzenlenmektedir.

BakTemYön uyarınca, Bakanlık temsilcisinin bulunmasının zorunlu olduğu GK’larda, temsilcinin yokluğunda alınan kararlar geçerli olmayacaktır. Temsilci bulunması zorunlu olmayan hallerde de GK'yı toplantıya çağıranların talep etmeleri halinde Bakanlık temsilcisi görevlendirilir. $\mathrm{Bu}$ hallerde de temsilcinin yokluğunda alınan GK kararları geçersiz olup (BakTemYön m. 32/4) temsilcinin katıldığı fakat toplantı tutanağını imzalamadığı hallerde de alınan kararlar geçersizdir (BakTemYön m. 26/5).

BakTemYön m. 26/5 ile m. 32/4, "geçersizlikten" söz etmekte fakat bu geçersizliğin türünün ne olacağını belirtmemektedir. Doktrinde çoğunlukla kabul edildiği üzere Bakanlık temsilcisinin GK toplantısında bulunmamasının (yahut tutanağa imza atmamasının) yaptırımı GK'da alınan kararların yokluğudur ${ }^{118}$. Buna göre, "toplantı tutanağının kanunda öngörülen şekilde tutulması ve temsilci tarafindan imzalamasının alınan kararların geçerlilik şartı olduğu" ifade edilmekte; bu görüş, Yargitay'ca da kabul görmektedir ${ }^{119}$.

\section{Kendigelen/Çonkar, s. 686.}

118 Arslanlı, s. 44; Moroğlu (2017), s. 132, 146; Teoman, (2012b), s. 239; Helvacı, s. 30; Bahtiyar, (2020), s. 167, dn. 230; Bahtiyar/Hamamcıoğlu, s. 77; Alışkan, s. 89; Şener, Oruç Hami (2019) Teorik ve Uygulamalı Ortaklıklar Hukuku, 4. Baskı, Ankara, Seçkin, s. 485. eTTK dönemi bakımından aynı değerlendirme için bkz. İmregün, s. 142; Yiğit, İlhan (2005) Anonim Ortaklık Genel Kurullarının İşleyişi ve Ortaya Çıkan Sorunlar, İstanbul, Vedat, s. 140.

119 “865 sayıl TK’nın 482. maddesi yoluyla kooperatiflerin umumi heyetleri hakkında da tatbik olunan 297 ve 378. maddeleri hükmünce Ticaret Vekaleti komiserini toplantılarda bulunup zabıtları imzalamış olması kararların muteberliği için zaruri bir şarttır. Demek ki bu zaruri şart gerçekleşmiş olmadığ 1 takdirde artık bir karar söz konusu olmayacaktır. Yani ortada 
Son dönemde konuyu ele alan Bahtiyar'a göre ise sorun, şirket iradesinin ortaya çıkma anı bakımından değerlendirilmelidir ${ }^{120}$. Zira ancak bu halde bakanlık temsilcisinin yokluğunda alınan yahut onun tarafından imza edilmemiş bulunan kararların hukuki akıbeti ortaya çıkabilir. Yazara göre, eTTK’nın aksine yalnızca kanunda sayılan GK toplantılarına Bakanlık temsilcisinin katılımının öngörülmesi temsilcinin varlığının GK kararlarının kurucu bir unsuru olmadığının kanıtıdır ${ }^{121}$. Bu bakımdan tescilin yahut

keenlemyekün bir karar bulunacaktır.” Yargitay HGK 6.2.1957, E. 50, K. 20 (Moroğlu, Erdoğan/Kendigelen, Abuzer (2014) İçtihatlı Notlu Türk Ticaret Kanunu ve İlgili Mevzuat, 10. Baskı, İstanbul, On İki Levha, s. 335).

“T.T.K.'nun 378. maddesinin kendisine atıfta bulunduğu aynı kanunun 297. maddesi sarahatine göre, genel kurul toplantılarında hükümet komiserinin o toplantınin başlangıcından sonuna kadar hazır bulunması ve müzakere zabıtlarının kanuna uygun bir şekilde tutulmalarına nezaret etmesi ve yapılan toplantının kanunun öngördüğ̈̈ şekil ve şartlara göre toplanıp toplanmadığını kontrol ve nezaret etmesi gerekli olup, olayda ise vazifeli hükümet komiserinin genel kurul toplantı zabtında yazılı olduğu şekilde kanunun öngördüğ̈̈ şartlara, riayet edilmeden toplantı yapıldığını belirtmiş ve toplantıda hazır bulunanların toplantıya devam etmekte ısrar etmeleri üzerine keyfiyeti zapta geçirerek genel kurulu terketmiş olmasına, hükümet komiserinin yukarıda değinildiği şekilde toplantıda bulunmaması TTK'nın 297 ve 378. maddelerinin gerekçesinde ve bu maddelerin kenar başlıklarında açıkça yazılı olduğu şekilde ( kararların muteberlik şartı) olmasına göre, ticaret sicil memurunun geçerli olmayan böyle bir kararı tescil etmemesi yerinde iken, mahkemece aksine düşünce ile ticaret sicil memurluğu kararının kaldırılmasına ve olağanüstü genel kurul zabıtlarının tescil ve ilanına karar verilmesi doğru görülmemiş ve kararın bozulması gerekmiştir.” Yargıtay 11. HD., 5.4.1982, E. 1512, K. 1491 (Kazancı İBB, Erişim Tarihi: 7.5.2018).

"Komiserin toplantıda bizzat hazır bulunduğunun zabıtlardan anlaşılması yeterli olmayıp ancak komiserin zabıtları imzalamış olması halinde alınan kararlar muteber hale gelir." Yargitay 11. HD., 14.5.1964, E. 1963/4265, K. 1775 (Moroğlu (2017), s. 132, dn. 217). KoopK. m. 87 dolayısıyla Kooperatif şirketlerde bu yönde bkz. "Görevlendirilen bakanlık temsilcisinin gelmemesi üzerine mahalli idare amirine durum bildirilmeli, temsilcinin bu bildirime ve bir saat beklenmesine rağmen yine gelmemesi halinde toplantıya başlanmalıdır. $B u$ prosedür uygulanmadan alınan kararların yok hükmünde sayılacağı..." Yargitay 23. HD., 24.2.2014, E. 737, K. 1273 (Kazancı İBB, Erişim Tarihi: 7.5.2018).

120 Bahtiyar, Mehmet (2019) “Anonim Şirketlerde Genel Kurul Toplantı Tutanağı ve Özellikle Kararların Hükümsüzlüğüne Etkileri”, Prof. Dr. Ersin Çamoğlu’na Saygı Günü- Şirketler Hukukunun Güncel Sorunları Sempozyumu, İstanbul, Seçkin, s. 56.

121 Bahtiyar, (2019), s. 57. 
bakanlık temsilcisinin tutanağı imzalamasının her durumda GK'da alınan kararın ortaya çıkması için zaruri olduğu yorumunda isabet bulunmamaktadır.

$\mathrm{Bu}$ açıdan daha önce kendisinin de iştirak ettiği yokluk yaptırımının her halükarda kabul edilmesinin sakıncalı olacağını ifade eden yazar, Bakanlık temsilcisinin katılımının zorunlu olduğu hallerde onun yokluğunda alınan kararların yok olması gerektiğini savunmakla birlikte temsilcinin toplantıda bulunup da çeşitli gerekçelerle toplantı tutanağını imzalanmaması halinde alınan kararların batıl olması gerektiğini ifade etmektedir ${ }^{122}$. Zira tutanak emredici nitelikte bir şekil kuralıdır ve şekle aykırılığın yaptırımı TBK m. 12 uyarınca butlandır ${ }^{123}$.

\section{KANAATIMİZ}

i. Kanaatimizce, AŞ’lerde GK'ya katılımı bir zorunluluk olarak öngörülen murahhas üyeler ile -kabulümüzce murahhas müdürlerin- en az bir YK üyesinin ve denetçinin GK toplantısına iştirak etmemesi, ilgili GK'da alınan kararların geçerliliğini etkilememelidir. Bu doğrultuda TTK m. 407 bir düzen hükmüdür. Böyle bir yükümlülüğün ikincil bir düzenleme olan yönetmelikle getirilmesi ise hukuk tekniğine uygun değildir. Nitekim, KomY'nin yürürlükte olduğu dönemde komiserin, katılımı zorunlu kişilerin bulunmadığını tespiti ile GK toplantısının açılmamasına karar vermesi doktrinde yoğun eleştirilere tabi tutulmuştur. Bu doğrultuda ilgili hükmün BakTemYön'e alınmaması, TTK m. 407'nin bir düzen hükmü olduğunu destekler niteliktedir ve bilinçli bir tercihtir.

Kaldı ki katılması zorunlu kişilerin toplantıya katılmamalarının yaptırımının GK'nın yapılamaması yahut alınan kararların mutlak olarak iptali olduğu sonucuna varılması bazı sakıncaları da beraberinde getirmektedir. $\mathrm{Bu}$ kişiler, toplantıya sürekli olarak katılmayıp GK’nın çalışmasını engelleyerek hükmü kötüye kullanabilirler ${ }^{124}$. Dolayısıyla, ilgili

\footnotetext{
Bahtiyar, (2019), s. 63.

123 Bahtiyar, (2019), s. 45. Aynı yönde bkz. Kırca(Şehirali Çelik/Manavgat), C. 2, s. 54.

124 Bu yönde bkz. Bahtiyar, (2019), s. 61; Kendigelen/Çonkar, s. 685; Helvacı, s. 44-45
} 
hükmün bir düzen hükmü olduğunun kabulü daha isabetlidir. Hal böyle olmakla birlikte GK’ya katılma yükümlülüğü altında bulunan kişilerin toplantıya katılmamasının pay sahiplerinin bilgi alma ve inceleme hakkını zedelemesi de söz konusu olabilir.

Bilgi alma hakkı toplantı dışında kullanılabileceği gibi GK toplantısı sırasında bilgi verme yükümlülerine soru sormak suretiyle de kullanılabilir. TTK m. 437/2'ye göre, bilgi verme yükümlüleri YK ve denetçilerdir. TTK m. 437/6'ye göre bilgi alma ve inceleme hakkı, esas sözleşmeyle ve şirket organlarından birinin kararıla kaldırılamayacağı yahut sınırlandırılamayacağı gibi hakkın kullanımının zorlaştırılmaması da gerekir. $\mathrm{Bu}$ bağlamda bilgi verme yükümlülerinin GK toplantısında hazır bulunması bir zorunluluktur. Bu yükümlülüğe aykırı davranış halinde GK'ya katılmakla birlikte ilgili konuda bilgi edinemeyen (örneğin finansal tabloların onaylanması maddesinde denetçilere soru yöneltemeyen) pay sahibinin TTK m. 437/5 uyarınca bilgi alma hakkını dava yoluyla kullanabilme imkanının yanı sıra karara olumsuz oy verip muhalefetini tutanağa geçirerek iptal davası açabilmesi gerekir (TTK m.446/1.a). Bu noktada Kendigelen/Çonkar'ın haklı olarak ifade ettiği üzere açılacak olan bir iptal davasında esasen bilgi alma hakkının ihlalinin alınan karar üzerinde etkili olup olmadığ inceleneceğinden, TTK m. 407’ye aykırılığın ayrıca bir iptal sebebi olarak öngörülmesi gerekli de değildir. Örneğin, pay sahibi tarafından YK'ya toplantı öncesi sorular yöneltilmiş ve buna bilgi alma hakkının gereğine uygun cevaplar verilmişse, artık bilgi verme yükümlülerinin toplantıya katılmadıklarından bahisle iptale gidilememelidir.

Tüm bu açıklamalar doğrultusunda TTK m. 407/1-2 hükmünün varlık sebebi sorgulanabilirse de anılan hükmün tamamen işlevsiz olduğundan bahsedilemez. Kanaatimizce burada, YK üyeleri ve denetçilerin görevlerinin doğası gereği yükümlülüğü olan GK’ya katılma, hukuki bir düzenleme ile pekiştirilmiş ve açılacak olan sorumluluk davalarında YK üye ve denetçilerinin GK'ya katılma zorunluluğunun bulunup bulunmadığının; YK üyelerinin azli halinde ise haklı sebebin mevcudiyetinin ayrıca tartışma konusu yapılmasının önüne geçilmiştir. 
ii. Bakanlık temsilcisinin bulunmadığı yahut GK toplantı tutanağını imzalamadığı hallerde alınan kararların akıbetinin ne olacağı sorusu ise TTK m. 422, BakTemYön m. 26/5, m. $32 / 4$ ve kanun koyucunun GK toplantılarında bakanlık temsilcisinin bulunmasına ilişkin iradesi ışı̆̆ında cevaplandırılmalıdır. BakTemYön m. 32/4, Bakanlık temsilcisinin yokluğunda alınan kararların geçerli olmadığını düzenlemektedir ${ }^{125}$. Kanaatimizce, bu geçersizliğin türü yokluktur. eTTK'da Bakanlık temsilcisinin tüm GK toplantılarında hazır bulunması bir zorunluluktu. BakTemYön m. 32 uyarınca ise yalnızca hükümde sayılan gündem maddelerinin söz konusu olduğu GK toplantılarında Bakanlık temsilcisi bulunmalıdır. eTTK'dan farklı olarak yalnızca bazı gündem maddelerinin müzakere edileceği GK toplantılarında Bakanlık temsilcisinin hazır bulunmakla yükümlü olması, kanaatimizce bu zorunluluğun mevcut olduğu hallerde Bakanlık temsilcisinin iradesinin, GK iradesinin tamamlayıcı bir kurucu unsuru olduğuna işaret eder ${ }^{126}$. Nasıl ki bir sözleşmenin kurucu unsuru tarafların karşılıklı ve birbirine uygun iradelerini beyan etmeleri ise hukuken geçerli bir GK kararının ortaya çıkabilmesi için pay sahiplerinin yanı sıra Bakanlık temsilcisinin de iradesinin GK kararına yansıması gereklidir. Bu nedenle, Bakanlık temsilcisinin katılmak zorunda olduğu bir GK toplantısına iştirak etmemesi halinde GK'da alınan kararlar yoklukla sakat olacaktır ${ }^{127}$.

BakTemYön m. 32/4, Bakanlık temsilcisinin GK toplantısına katılmaması halini düzenlemekte, temsilcinin katılmasına karşın GK toplantı tutană̆ını imzalamaması halinden ise söz etmemektedir. TTK m. 422 ve BakTemYön m. 26/5, GK toplantı tutanağının Bakanlık temsilcisi tarafından imzalanacağını aksi halde tutană̆ın geçersiz olacağını düzenlemektedir ${ }^{128}$.

125 Bahtiyar, "geçersizdir" sözcügünün butlan yaptırımını karşılaması gerektiğini ifade etmektedir, (2019), s. 59. Kanaatimizce anılan ifade "yokluk" yaptırımını işaret etmektedir. Bahtiyar ise aynı gerekçeyle farklı sonuca varmaktadır, (2019), s. 57.

Kurca/Şehirali Çelik/Manavgat, C. 2, s. 10, Bakanlık temsilcisinin mevcudiyetinin gerekli olduğu ifade edilmek suretiyle bu yönde bkz. Poroy, Reha/Tekinalp, Ünal /Çamoğlu, Ersin (2003) Ortaklıklar ve Kooperatif Hukuku, 9. Baskı, İstanbul, Vedat, N. 696. geçersizliğinin GK kararlarının geçersizliğine yol açtığı kabul edilmektedir. Tutanağın işlevi ve önemi hakkında detaylı bilgi için bkz. Pulaşı, C. 1, s. 1000 vd. 
Her ne kadar doktrinde hemen hemen ihtilafsız biçimde ${ }^{129}$ Bakanlık temsilcisinin toplantıya katılmaması ile tutanağa imza atmaması hali bir ayrım yapılmaksızın yokluk yaptırımına tabi tutulsa da kanaatimizce Bakanlık temsilcisinin toplantıya katılmaması ile toplantı tutanağını imzalamaması hallerini birbirinden ayırmak isabetli olacaktır. Bu bağlamda zorunlu hallerde bakanlık temsilcisinin GK toplantısına katılmasına karşın tutanağı herhangi bir sebeple imzalamamış olmasına yokluk yaptırımının uygulanması tutanağa, GK kararının ortaya çıkışı bakımından bir kuruculuk atfeder ki bu her zaman isabetli olmayan bir tespittir. Bu sebeple tutanağın kararın ortaya çıkması bakımından kurucu mu olduğu yoksa yalnızca GK'da alınan kararların, pay sahiplerinin özelliklerinin ve verdikleri oyların yönünün tespitini mi sağladığ sorusu önem taşımaktadır.

Doktrinde bir GK kararının ortaya çıkması için bir kurulun yapılması ve bu kurulda bir karar alınmış olması gerektiği ifade edilmektedir ${ }^{130}$. TTK m. 422'de de tutanağın, toplantıya katılan pay sahipleri, payların itibari değerleri gibi bilgilerin tespitini içeren bir belge olduğu düzenlenmektedir. Ticaret siciline tescilin kurucu olduğu sermaye artırımı gibi ayrıksı durumlar bir kenara bırakıldığında GK'da alınan kararlar, alındıkları anda hüküm ve sonuç doğurur. Esas sözleşme değişiklikleri bakımından bu husus, TTK m. 455'te düzenlenmektedir. Hükmün mefhumu muhalifinden değiştirme kararının iç ilişkide alınma anından itibaren hüküm ve sonuç doğurmaya başlayacağı anlaşılmaktadır.

Kanaatimizce, Bakanlık temsilcisinin sonuna kadar nezaret ederek kanuni vazifesini ifa ettiği fakat tutanağı imzalamadığı hallerde, alınan kararların yoklukla malul olduğunu söylemek hakkaniyete aykırı sonuçlar doğurabilecektir. Zira Bakanlık temsilcisinin kanunda sayllan hallerde yükümlülüğü ilgili toplantıda hazır bulunarak, toplantıya nezaret etmek ve BakTemYön m. 34'teki görev ve sorumlulukları yerine getirmektir. Bunun sonucunda ilgili hususların şerh düşüldüğü tutanağın ilgililer ve son tahlilde Bakanlık temsilcisi tarafından imzalanması tamamlayıcı bir şekil şartı niteliği

129 İmregün, s. 152; Moroğlu (2017), s. 147; Arslanlı, s. 65; Poroy/Tekinalp/Çamoğlu, C.1, N. 722a; Pulaşlı, C. 2, s. 1013; Alışkan, s. 89.

130 Moroğlu (2017), s. 77, 135. 
taşımaktadır. Dolayısıyla Bakanlık temsilcisinin sonuna kadar katıldığı bir GK toplantısından zorunlu bir hal nedeniyle ayrılması sonucu tutanağı imzalamamış olması durumunda alınan kararların yokluğundan değil, şekil şartına aykırılık nedeniyle butlanından bahsedilmelidir. Bu ayrımın yapılması önemlidir zira pratikte butlan ile yokluk arasında sonuç itibariyle bir fark olmadığ 1 ileri sürülse de yokluğun aksine butlanı ileri sürmek hakkın kötüye kullanılması (TMK m.2) teşkil edebilir. Bu itibarla, pay sahiplerinin iradelerinin yok sayılması suretiyle Bakanlık temsilcisinin sonuna kadar nezaret ettiği bir toplantıdan mazereti sonucu tutanağı imzalamadan ayrılması halinde alınan kararların batıl olduğu ileri sürülebilirse de pay sahiplerince bu iddianın ileri sürülmesinin hakkın kötüye kullanılması niteliğinde olduğu savunması yapılabilecektir ${ }^{131}$. Hemen belirtmek gerekir ki bu halde Bakanlık temsilcinin BakTemYön m. 39 uyarınca sorumluluğu da gündeme gelebilecektir.

\section{SONUÇ}

Anonim şirket GK'ları bir pay sahipleri kurulu olup, olağan katılımcıları pay sahipleridir. Pay sahiplerinin yanında hiç kuşkusuz pay sahiplerinin temsilcileri, intifa hakkı sahipleri ve kendilerine bu hususta yetki verilmiş ise rehin, hapis hakkı vb. sözleşmenin taraflarının da GK’ya katılma hakkı bulunmaktadır.

Bu kimseler için öngörülmüş bulunan GK’ya katılma hakkı diğer bazı kişiler için ise hem bir hak hem de bir yükümlülük olarak karşımıza çıkmaktadır. TTK'nın 407. maddesi uyarınca murahhas üyeler ile en az bir YK üyesinin, denetçilerin ve Bakanlı temsilcisinin GK'ya katılması bir zorunluluk olarak öngörülmüştür. Mehaz Alman hukukuna bakıldığında bu yükümlülük tüm YK üyelerine ait iken; Türk hukukunda niçin yalnızca bir YK üyesi bakımından bu zorunluluğun getirildiği net değildir. Kanaatimizce

131 Butlan ile yokluk arasındaki farklılık kendini, tahvil imkânının varlığı ve geçersizliği ileri sürmenin hakkın kötüye kullanılması teşkil edip etmediği noktalarında göstermektedir. Hukuki sonuç bakımından iki yaptırım türünün bir farkı olmadığı yönünde bkz. Pulaşlı, C. 2, s. 1013, dn. 525 . 
olması gereken hukuk bakımından madde metni "YK üyelerinin tamamı ile murahhas müdürlerin" GK toplantısına katılım zorunluluğunu açıça ifade etmelidir.

$\mathrm{Bu}$ zorunluluğa uyulmaması halinde ilgili kişilerin nasıl bir yaptırımla karşılaşacakları hususunda ise kanun koyucu bir düzenleme yapmamıştır. TTK m. 407, gerekçede de belirtildiği üzere bir düzen hükmü olup, YK ile denetçilerin GK toplantısına katılımlarına ilişkin olağan yükümlülüklerinin kanuni düzenleme ile pekiştirilmesine hizmet etmektedir. Bu noktada, YK üyelerinden en az biri, murahhas üyeler ile müdürler ve denetçilerin GK toplantısına katılmaması, GK kararlarının geçerliliğine kural olarak etkili değildir, ancak bu kişilerin sorumluluğunu doğurabilir. Ne var ki toplantıya katılmama sonucu pay sahiplerinin bilgi alma hakkının zedelenmesi söz konusu ise, GK'da alınan kararlar iptal davasına konu olabilecektir. Katılma yükümü her ne kadar YK üyelerinden en az biri için söz konusu olsa da, katılmama durumunda sorumluluk tüm YK üyelerine ait olmalıdır.

Bakanlık temsilcisinin katılması zorunlu olan GK toplantısına katılmaması durumunda, alınan kararlar, Bakanlık temsilcisinin varlığının bu kararların ortaya çıkışı bakımından bir kurucu unsur olması nedeniyle yoklukla sakat olmalıdır. Buna karşın, toplantıya nezaret görevini yerine getiren Bakanlık temsilcisinin tutanağı imzalamaması ise ancak şekil şartına aykırılık teşkil eder. Bu durumda kararın yok olmayıp, şekil şartına aykırılık nedeniyle batıl olacağının ve ancak hakkın kötüye kullanılması söz konusu değil ise ileri sürülebileceğinin ilgililerin menfaatine olduğunun kabulü gerekir. 


\section{KAYNAKÇA}

Akdăg Güney, Necla (2016) Anonim Şirket Yönetim Kurulu, 2. Bask1, İstanbul, Vedat.

Alışkan, Murat (2007) Türk Ticaret Kanunu'na Göre Sanayi ve Ticaret Bakanlığı'nın Anonim Şirketleri Denetlemesi ve İlgili Fesih Davaları, İstanbul, Legal.

Antalya, Gökhan/Topuz, Murat (2019) Medeni Hukuk Giriş Temel Kavramlar Başlangıç Hükümleri, 3. Baskı, Ankara, Seçkin.

Arslanlı, Halil (1960) Anonim Şirketler II-III Anonim Şirketin Organizasyonu ve Tahviller, 3. Baskı, İstanbul, Fakülteler Matbaası.

Ayan, Özge (2012) “6102 sayılı Türk Ticaret Kanunun 428 Maddesinde Düzenlenen Organın Temsilcisi ve Bağımsız Temsilci”, Gazi Üniversitesi Hukuk Fakültesi Dergisi, C. 16, S. 3, s. 1-46.

Bahtiyar, Mehmet (2007) “Anonim Ortaklıkta Denetçilerin Rapor Hazırlamamaları ve Olağan Genel Kurul Toplantısına Katılmamaları Nedeniyle Komiserin Toplantıyı Açamamasının Sonuçları (Somut Bir Olaya İlişkin Notlar)", Maltepe Üniversitesi Hukuk Fakültesi Dergisi, Prof. Dr. Aydın Aybay’a Armağan.

Bahtiyar, Mehmet (2019) “Anonim Şirketlerde Genel Kurul Toplantı Tutanağı ve Özellikle Kararların Hükümsüzlügüne Etkileri”, Prof. Dr. Ersin Çamoğlu’na Saygı Günü- Şirketler Hukukunun Güncel Sorunları Sempozyumu, İstanbul, Seçkin, s. 35-65.

Bahtiyar, Mehmet (2020) Ortaklıklar Hukuku, 13. Baskı, İstanbul, Beta.

Bahtiyar, Mehmet/Hamamcioğlu, Esra (2014) Yeni TTK’ya Göre Anonim Ortaklık Genel Kurul Toplantıları, İstanbul, Beta.

Bilgili, Fatih/Demirkapı, Ertan (2013) Şirketler Hukuku, 9. Baskı, Bursa, Dora.

Çamoğlu, Ersin (2010) Anonim Ortaklık Yönetim Kurulu Üyelerinin Hukuki Sorumluluğu, 3. Baskı, İstanbul, Vedat.

Doğanay, İsmail (1990) Türk Ticaret Kanunu Şerhi C.1, 3. Baskı, Ankara, Feryal Matbaası. 
Helvacı, Mehmet (1997) Anonim Şirket Genel Kurul Toplantıları Ve Bu Toplantılarda Bulunacak Sanayi ve Ticaret Bakanlığı Komiserleri Hakkında Yönetmelik Gereği Ticaret Ortaklıklarının Özellikle Anonim Ortaklıkların Genel Kurullarının Yapılması, İstanbul, Beta.

İmregün, Oğuz (1989) Anonim Ortaklıklar, 4. Baskı, İstanbul, Yasa.

Karamanlıŏlu, Argun (2016) Anonim Ortaklıkta Pay Sahibinin Genel Kurul Toplantısında Temsili, İstanbul, Vedat.

Kaya, Arslan (2001) Anonim Ortaklıkta Pay Sahibinin Bilgi Alma Hakkı, Ankara, Banka ve Ticaret Hukuku Araştırma Enstitüsü.

Kendigelen, Abuzer (1994) Anonim Ortaklık Payı Üzerinde İntifa Hakkı, İstanbul, Beta.

Kendigelen, Abuzer (2012) Türk Ticaret Kanunu Değişiklikler, Yenilikler ve İlk Tespitler, 2. Baskı, İstanbul, On İki Levha.

Kendigelen, Abuzer/Çonkar,Halil (2019) “Genel Kurula İlişkin Uygulamada Karşılaşılan İki Güncel Sorun”, Prof. Dr. Sabih Arkan’a Armağan, s. 675-690.

Karasu, Rauf (2015) Anonim Şirketlerde Emredici Hükümler İlkesi, 2. Baskı, Ankara, Yetkin.

Kırca, İsmail/Şehirali Çelik, Feyzan Hayal/Manavgat, Çağlar (2013) Anonim Şirketler Hukuku C.1, Ankara, Banka ve Ticaret Hukuku Enstitüsü.

Kırca, İsmail/Şehirali Çelik, Feyzan Hayal/Manavgat, Çağlar (2016) Anonim Şirketler Hukuku C. 2/II- Genel Kurul Kararlarının Hükümsüzlüğü, Ankara, Banka ve Ticaret Hukuku Enstitüsü.

Kocabıyık, Sami (2018) Bağımsız Denetçinin Üçüncü Kişilere Karşı Hukuki Sorumluluğu, Ankara, Seçkin.

Köksal, Aytaç (2010) “Türk Ticaret Kanunu Tasarısının 309 ila 406. Maddeleri Arasında Düzenlenen Denetçinin Anonim Ortaklığın Bir Organı Olup Olmadığı Sorunu”, Prof. Dr. Fırat Öztan'a Armağan C.1, Ankara, s. 1387-1419.

Moroğlu, Erdoğan/Kendigelen, Abuzer (2014) İçtihatlı Notlu Türk Ticaret Kanunu ve İlgili Mevzuat, 10. Baskı, İstanbul, On İki Levha. 
Moroğlu, Erdoğan (2012) 6102 sayılı Türk Ticaret Kanunu Değerlendirme ve Öneriler, 7. Baskı, İstanbul, On İki Levha.

Moroğlu, Erdoğan (2017) Anonim Ortaklıkta Genel Kurul Kararlarının Hükümsüzlügü̈, 8. Baskı, İstanbul, On İki Levha.

Moroğlu, Erdoğan (2015) Oy Sözleşmeleri, 5. Baskı, İstanbul, Vedat.

Narbay, Şafak (2003) Anonim Ortaklıkta Pay Defteri, Ankara, Seçkin.

Oğuzman, Kemal/Seliçi, Özer/Oktay Özdemir Saibe, (2017) Eşya Hukuku 20. Bask1, İstanbul, Vedat.

Okutan Nillson, Gül (2009) Türk Ticaret Kanunu Tasarısı'na Göre Şirketler Topluluğu Hukuku, İstanbul, On İki Levha.

Orbay Ortaç, Nurdan/Al Kılıç, Şengül (2018) “Anonim Şirket Yönetim Kurulu Üyelerinin ve Murahhasların Genel Kurula Katılması”, TFM, C.4, S. 2, s. 211-238.

Özdemir, Türkay/Yiğit, İlhan (2007) Anonim Şirket Genel Kurullarında Pay Sahibinin temsili ve Türk Ticaret Kanunu Tasarısı, Prof. Dr. Hüseyin Ülgen'e Armağan C.1, İstanbul, s. 433-466.

Poroy, Reha/Tekinalp, Ünal /Çamoğlu, Ersin (2019) Ortaklıklar Hukuku I, 14. Bask1, İstanbul, Vedat (C.1)

Poroy, Reha/Tekinalp, Ünal/Çamoğlu, Ersin (2019) Ortaklıklar Hukuku II, 14. Bask1, İstanbul, Vedat (C.2).

Poroy, Reha/Tekinalp, Ünal /Çamoğlu, Ersin (2003) Ortaklıklar ve Kooperatif Hukuku, 9. Baskı, İstanbul, Vedat.

Pulaşlı, Hasan (2018) 6102 sayılı Türk Ticaret Kanunu'na Göre Şirketler Hukuku Şerhi, C. 1, 3. Baskı, Ankara, Adalet (C. 1).

Pulaşlı, Hasan (2018) 6102 sayılı Türk Ticaret Kanunu'na Göre Şirketler Hukuku Şerhi, C.2, 3. Baskı, Ankara, Adalet (C. 2).

Sarıkaya, Sinan (2019) Şirket Birleşmelerinde Ortakların Dava Yoluyla Korunması, İstanbul, Vedat.

Şener, Oruç Hami (2019) Teorik ve Uygulamalı Ortaklıklar Hukuku, 4. Baskı, Ankara, Seçkin.

Tekinalp, Ünal (2013) Sermaye Ortaklıklarının Yeni Hukuku, 3. Baskı, İstanbul, Vedat. 
Teoman, Ömer (2012) “Anonim Ortaklık Genel Kurul Toplantısına İlişkin Hazirun Cetveli”, Tüm Makalelerim C.1-2, 2. Baskı, İstanbul, On İki Levha, s. 1015-1034 (2012c).

Teoman, Ömer (2012) “Anonim Ortaklıklarda Yönetim Kurulu Üyelerinin Genel Kurul Toplantılarına Bizzat Katılma Yükümü Var Mıdır?” Tüm Makalelerim C.1-2 içinde, İstanbul, On İki Levha, s. 415-421 (2012a).

Teoman, Ömer (2012) “Anonim Ortaklıkta Paylar Üzerinde İntifa Hakkı Bulunması Durumunda Oy Hakkı Dışındaki Yönetim Haklarının Kimin Tarafından Kullanılacağı Sorunu”, Tüm Makalelerim C.1-2, 2. Baskı, İstanbul, On İki Levha, s. 365-375 (2012d).

Teoman, Ömer (2012) "Yürürlükteki Hukukumuza Ve Türk Ticaret Kanunu Tasarısına Göre Anonim Ortaklık Genel Kurul Toplantılarına Katılmak Zorunda Olanlar”, Tüm Makalelerim C.3, İstanbul, On İki Levha, s. 221-239 (2012b).

Teoman, Ömer (1983) Anonim Ortaklıkta Pay Sahibinin Oy Hakkından Yoksunluğu, Ankara, Banka ve Ticaret Hukuku Enstitüsü.

Teoman, Ömer (2012) “Anonim Ortaklık Genel Kurul Toplantılarına Dinleyicilerin Katılması”, Tüm Makalelerim C.1-2, İstanbul, On İki Levha. s. 245-262 (2012e).

Ünal, Mustafa (1982) “Anonim Ortaklıklarda Yönetim ve Yönetim Görevlerinin Murahhaslara Bırakılması”, BATIDER, C.10, S.3, s. 49-89.

Yayla, Ümit (2013) Yeni Türk Ticaret Kanunu ve Sermaye Piyasası Kanunu Uyarınca Anonim Ortaklık Genel Kurulları Elektronik Genel Kurullar, İstanbul, On İki Levha.

Yılmaz, Abdüssamet (2020) Anonim Ortaklık Payının Rehin ve Hapis Haklarına Konu Olması, İstanbul, On İki Levha.

Yiğit, İlhan (2005) Anonim Ortaklık Genel Kurullarının İşleyişi ve Ortaya Çıkan Sorunlar, İstanbul, Vedat. 